\title{
Еще раз о валах на Керченском п-ове и их датировках (к статье А.А. Супренкова «Предварительные результаты разведок на валах восточного Крыма в 2019 г.»)
}

\author{
Ермолин А.Л. \\ Институт Археологии им. Цинмана, Университет Хайфы, Израиль, \\ Гора Кармел, Хайфа, 31905, Израиль \\ E-mail: doryerm@gmail.com
}

\begin{abstract}
Аннотация. В статье ставится вопрос о датировке древней архитектуры и оборонительных валов Тиритакского, Безкровного и Узунларского. На основании археологических изысканий и раскопок, проведенных Керченской археологической экспедицией в 2000 -е гг., предложен план и линия оборонительных сооружений. Кроме того, на основании археологических данных можно сделать вывод, что, помимо этой оборонительной военной архитектуры, существовала еще неизвестная ранее линия обороны - Восточная линия обороны. В течение 2016-2019 гг. были заново исследованы все оборонительные сооружения - рвы и валы - на Керченском п-ове под руководством А.А. Супренкова. В статье приводится критика многих выводов археолога.
\end{abstract}

Ключевые слова. Боспор, валы, оборонительная линия, оборонительная система, Крым.

Для цитирования: Ермолин А.Л. 2021. Еще раз о валах на Керченском п-ове и их датировках (к статье А.А. Супренкова «Предварительные результаты разведок на валах восточного Крыма в 2019 г.»). Via in tempore. История. Политология, 48 (3): 554-578. DOI 10.52575/2687-0967-2021-483-554-578.

\section{Concerning the ramparts on the Kerch peninsula and their dating (comments to the article by A.A. Suprenkov «Preliminary results of exploration on the ramparts of the eastern Crimea in 2019»)}

\author{
Alex L. Ermolin \\ Zinman Institute of Archaeology, University of Haifa, \\ Mount Carmel, Haifa 31905, Israel \\ E-mail: doryerm@gmail.com
}

\begin{abstract}
The article raises the question of dating the ancient architecture and the defensive ramparts of Tiritaka, Bezkrovny and Uzunlar. On the basis of archaeological surveys and excavations carried out by the Kerch archaeological expedition, the plan and line of defenses are proposed. Furthermore, on the basis of archaeological data, it is concluded that in addition to this defensive military architecture, there was also a previously unknown line of defenses - the Eastern Line of Defense. During 2016-2019 all defensive structures - ditches and ramparts - on the Kerch Peninsula were investigated, under the leadership of A.A. Suprenkov. The article criticizes many of the archaeologist's findings. The article offers detailed clarifications on most positions regarding the ramparts and ditches of the European Bosporus. 10 conceptual conclusions are made, revising the conclusions of A.A. Suprenkov. The conclusions are based on many years of field research and exploration of the author in the Eastern Crimea.
\end{abstract}

Keywords. Bosporus, ramparts, defensive line, defensive system, Crimea. 
For citation: Ermolin A.L. 2021. Concerning the ramparts on the Kerch peninsula and their dating (comments to the article by A.A. Suprenkov «Preliminary results of exploration on the ramparts of the eastern Crimea in 2019»). Via in tempore. History and political science, 48 (3): 554-578 (in Russian). DOI 10.52575/2687-0967-2021-48-3-554-578.

\section{Введение}

Время от времени в археологической литературе появляются статьи об исследовании древних земляных оборонительных сооружений - рвов и валов, в дальнейшем будем называть их просто валами. С 2016 по 2019 гг. были исследованы практически все основные подобные сооружения на Керченском п-ове: Тиритакский вал, вал Безкровного, Узунларский и Акмонайский валы. Основным исследователем этих сооружений стал А.А. Супренков, к. и. н., сотрудник Института археологии РАН. В сборнике «Древности Боспора», наиболее престижном издании по археологии и истории Боспора, в 25 томе была опубликована его статья [Супренков, 2020, с. 360-375], в которой кратко представлены результаты не только разведок, но и раскопок этих оборонительных сооружений, имевших место в ходе недавних охранно-спасательных археологических работ, и предложена их датировка. То есть сделан своего рода итоговый краткий отчет, касающийся местоположения, устройства, боевого применения и датировки земляных оборонительных сооружений Европейской части Боспора. Считаем необходимым высказаться по поводу этой публикации.

\section{Результаты и их обсуждение}

Начнем с того, что уже во второй строке данной статьи сказано, что речь пойдет о «масштабных земляных работах» в 2016-2019 гг., хотя в названии заявлены разведки 2019 г. Далее приводится датировка Узунларского и Тиритакского валов: «Так, мы считаем, что оба вала были созданы единовременно либо в конце IV в. до н. э., либо несколько позднее, а затем обновлены и укреплены во время правления Асандра» [Супренков, 2020, c. 360]. Надо думать, что это выводы были сделаны на основании изысканий предшественников и работ А.А. Супренкова.

Здесь стоит ещё раз остановиться на этих датировках, начав с Узунларского вала. Итак, на сегодня устоявшееся мнение таково: вал был построен в конце IV - начале III вв. до н. э. Оно было высказано и обосновано А.А. Масленниковым в его монографии и вобрало в себя представления большинства предыдущих исследователей, при этом исключив более раннюю дату - времена поздней бронзы. А.А. Масленников пишет: «Таким образом, ряд находок и наблюдений заставляют склониться к гипотезе о возведении Узунларского вала либо в IV в. до н. э., но всё же после присоединения Феодосии (Хотя логичнее бы предположить обратный порядок событий). Либо это имело место еще позднее - в начале III в. до н. э. Последний вариант представляется нам наиболее предпочтительным» [Масленников, 2003, с. 108].

В своей статье, напечатанной в РА № 12020 г., А.А. Масленников подтверждает эти датировки, при этом фактически соглашается с датировкой вала Безкровного - I в. до н. э. [Масленников, 2020, с. 77].

Какие же находки приводятся для обоснования указанных датировок? Это отдельные фрагменты керамики в заполнении рва и насыпи вала, которые, естественно, не связаны напрямую со строительством этого (и других) сооружений. Единственное, о чем могут «говорить» подобные находки, это о том, что вал был насыпан не ранее времени её бытования. Что касается заполнения рва, то там вообще в силу самых разных причин может оказаться любая керамика, хотя, конечно, стратиграфия её местонахождения имеет известное значение. Некую более или менее определённую датировку, как-то «привязан- 
ную» ко времени соответствующих работ, может дать только единовременное скопление керамического материала, попавшего в нижние слои заполнения рва или в грунт и оставленного переходом через него из культурного слоя какой-то поселенческой структуры, непосредственно располагавшейся рядом.

Классическим примером такого рода ситуации можно считать раскопки рва у поселения Голубицкая 2. Тут Д.В. Журавлевым в заполнении рва на уровне его дна был выявлен довольно представительный набор керамики. Приведём соответствующие выводы автора этих раскопок: «Оборонительный ров, согласно стратиграфическим наблюдениям и датировкам керамического материала, был сооружен вскоре после основания поселения, не позднее 3-й четв. VI в. до н. э.» [Журавлев, 2020, с. 248]. Датировка здесь совершенно однозначна, хотя Д.В Журавлев до сих пор так и не выяснил местоположение вала относительно рва, а равно и его назначение.

Полагаем, что ров у поселения Голубицкая 2 являлся пограничным и определял границы Боспора на конец VI в. до н. э. Кроме того, он мог быть одним из сооружений, упоминаемых Геродотом, как Киммерийские укрепления или валы «детей слепых рабов».

Ничего аналогичного в отношении Узунларского вала мы сказать пока не можем. За время раскопок кроме единичных и незначительных фрагментов керамики IV-III вв. до н. э. не было найдено ни одного керамического комплекса этого времени и даже признаков синхронных оборонительных сооружений. Курганы, расположенные в непосредственной близости от Узунларского вала, не имеют к нему никакого отношения, и датировать вал по курганам нельзя.

Еще одним исследователем Узунларского вала является С.Г. Колтухов, он также считает, что вал был построен в IV - начале III вв. до н. э., и эта дата тоже основана на находках незначительных фрагментов керамики IV в. до н. э., найденных в ходе раскопок Узунларского вала в 2002 г. [Колтухов и др., 2003, с. 179] и ранее при исследовании вала перед оборудованием полей в районе Горностаевки мелиоративными системами. Мы непосредственно приняли участие в раскопках Узунларского вала в 2002 и в 2005 гг. [Колтухов и др., 2003, с. 176-183; Колтухов и др., 2006, с. 340-347] и можем с полной ответственностью заверить, что в ходе этих раскопок были найдены незначительные фрагменты керамики, не имеющие к датировке самого сооружения никакого отношения. Под валом вполне могла оказаться керамика IV в. до н. э. при его сооружении и в I в. до н. э., и в любое другое время, после IV в. до н. э.

Эта датировка - IV - начало III вв. до н. э. - связана также с мнениями современных авторитетных археологов, классиков, сконцентрировавших в своих исследованиях опыт предыдущих ученых. Это мнение, как уже говорилось выше, поддержано и А.А. Супренковым. Но следует рассмотреть аргументацию, на которой он строит свои выводы. Начнем с научного аппарата в его статьях [Супренков, 2018, с. 230-257; Супренков, 2019, c. 103-111].

В статье 2018 г. [Супренков, 2018, с. 230-257] нас интересует хронология Узунларского вала; об этом автор пишет следующее: «... Обратимся к самому интригующему вопросу: уточнению времени возникновения Узунларского вала по результатам наших раскопок. Многочисленный материал из слоя у башни и заполнения П-образного рва, а также находки в самом рву (хотя и единичные), указывают на IV в. до н. э. К сожалению, малое количество узко-датирующего материала не даёт нам сколько-либо более точной хронологии. Согласимся с нашими предшественниками в том, что это произошло уже в период после присоединения Феодосии и не раньше середины IV в. до н. э. [Масленников, 2003, с. 209, 230]. Однако принятые датировки таких центров производства амфор как Фасос, Хиос, Гераклея, Менда, Икос указывают на период до начала III в. до н. э.». 
Как мы здесь видим, датировка вала делается на основании материала, найденного в слое курганного некрополя IV - начала III вв. до н. э., ведь строительные остатки башни (?) были расположены на кургане IV в. до н. э. (рис. 1). Но какое отношение курганный некрополь середины IV - начала III вв. до н. э. имеет к валу, если курганы находятся как к западу от вала, так и к востоку? Вполне логично, что и материал некрополя будет какимто образом попадать в более поздний ров и вал, если они его прорезают. То же относится и к поселениям IV - начала III вв. до н. э.: эти поселения есть как с одной, так и с другой стороны Узунларского и других валов.

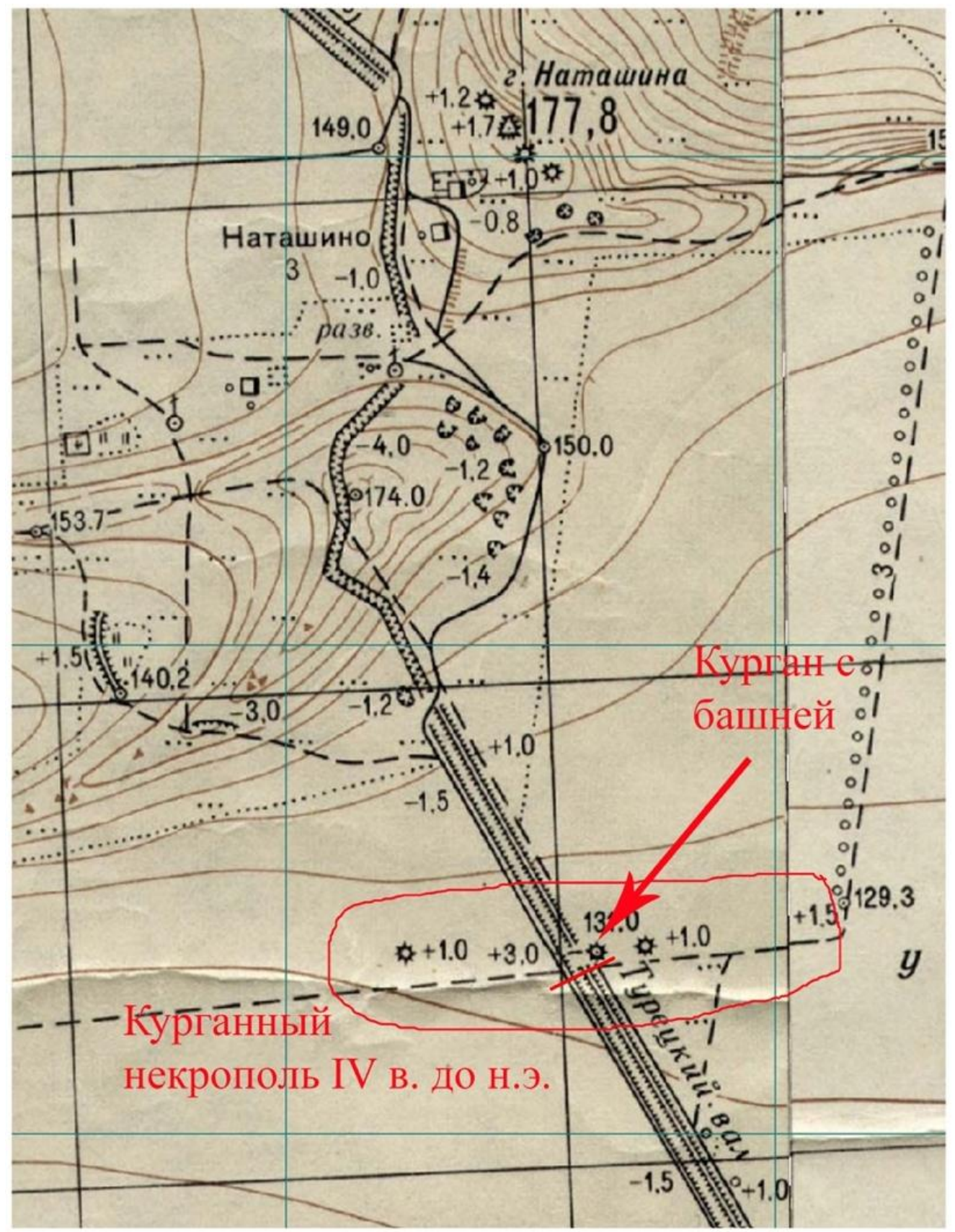

Рис. 1. Место раскопок Узунларского вала в 2017 году А.А. Супренковым. Красным обведен курганный некрополь IV в. до н. э., стрелкой указано местоположение кургана с башней. Ниже кургана с башней указано место раскопок рва и вала

Fig. 1. Excavation site of the Uzunlar shaft in 2017 A.A. Suprenkov. The mound necropolis of the 4th century is circled in red. BC, the arrow indicates the location of the mound with a tower. Below the mound with a tower is the site of the excavation of the ditch and the rampart 
Если рассматривать Боспор с точки зрения военных действий на его территории с середины IV в. до н. э. и по начало III в. до н. э., то это было самое мирное и богатое время для Боспора. На всей его территории до сих пор не найдено ни одного оборонительного сооружения этого времени. Зачем же тогда копать ров в это время?

Если же искать период, когда оставляются все неукрепленные поселения и строятся крепости на побережье Азовского моря, пролива и Черного моря, то этот период начинается в начале 2-й четв. III в. до н. э.; при этом ближайшая крепость находится минимум в 20 км от места раскопок и, соответственно, самого вала. В линии самого Узунларского вала, как уже было сказано, нет даже признаков укреплений этого времени, а самые ранние укрепления - сторожевые башни - датируются 40-ми гг. І в. до н. э. - временем правления Асандра. И таких башен насчитывается 19 (!) [Ермолин, 2019, с. 30-98], причем 4 из них раскопаны и совершенно точно продатированы А.А. Масленниковым. То есть Узунларский вал не восстанавливался в 40-х гг. І в. до н. э., а был построен в это время. Здесь стоит вспомнить Страбона и его размещение башен: Страбон считал, что на каждые 10 стадий приходилась одна башня, что приблизительно подтверждается археологически, и если 34 км вала от Азовского моря до оз. Узунлар разделить на 19 башен, то выходит, что между ними находится в среднем 1,8 км.

Что касается второго этапа капитальной перестройки вала, то его надо связать с очередным критическим моментом для истории Боспора - проходом гуннов через Керченский полуостров в 453 г. Именно к этому событию готовились боспоряне, был выкопан вал Елены (рис. 2) [Ермолин, 2006, с. 90-100], были восстановлены Узунларский вал и фактически построен заново Тиритакский вал [Ермолин, 2005, с. 171-183]. По нашему мнению, и Семеновский (он же Ак-Ташский, Казантипский) вал также был построен в это время (453 год), и поселение Семеновка, находящееся в 3,5 км к северу от него, к валу не имеет никакого отношения. Задачей этого вала было направлять гуннов в нужное «русло» (рис. 2). Здесь стоит заметить, что А.А. Масленников датировал этот вал I в. до н. э. [Масленников, 2003, с. 214].

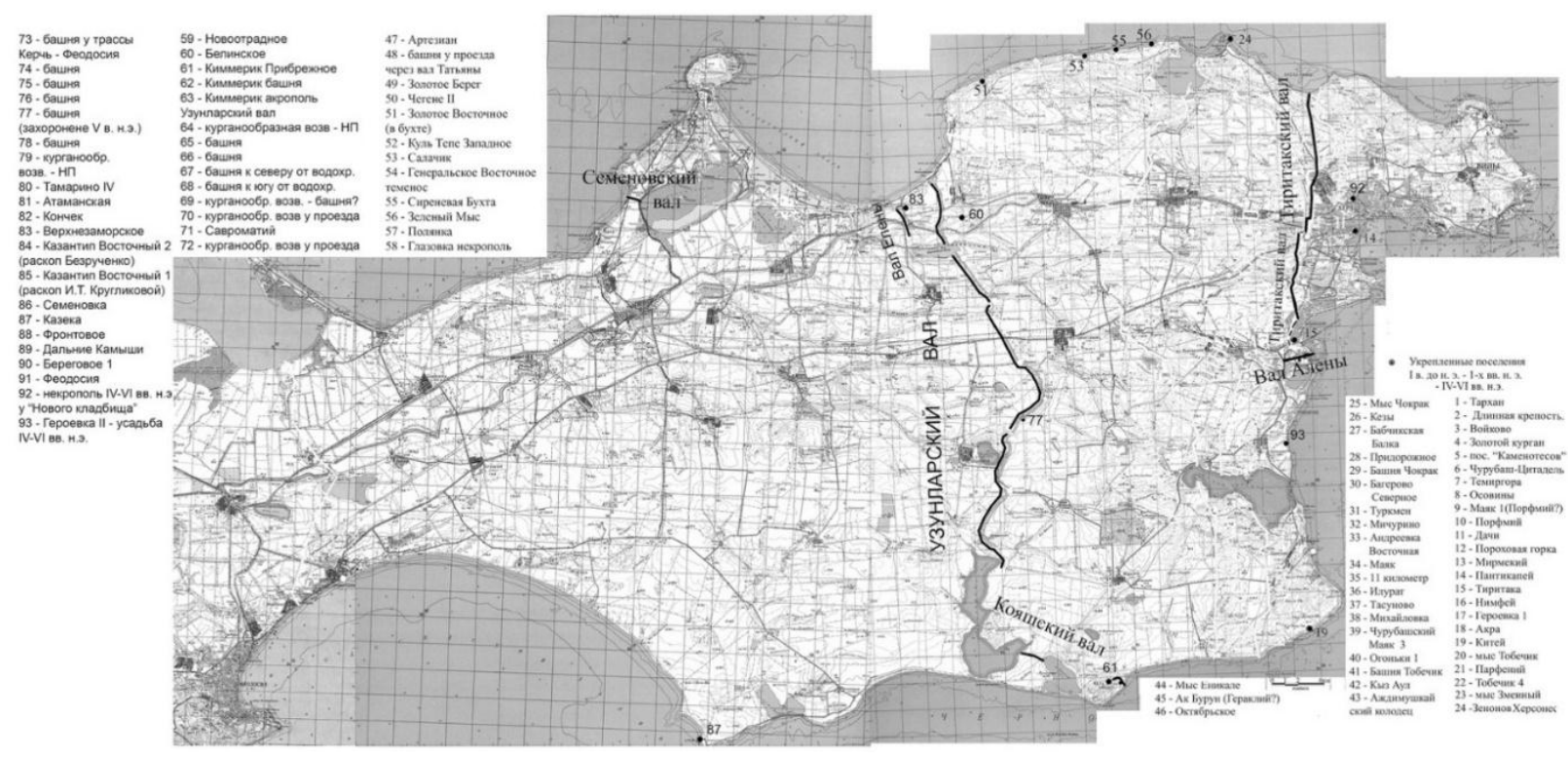

Рис. 2. Европейский Боспор в IV-V вв.

Fig. 2. European Bosporus in the IV-V centuries

Теперь по поводу «натурализации» Узунларского вала, о котором якобы все известно. По нашему мнению, далеко не на все вопросы здесь есть ответы. Например, неизвестно, как закачивался Узунларский вал в районе Азовского моря, доходил ли вал до уре- 
за воды, а это 500 м прибрежной террасы сейчас и больше 1 км на момент его постройки; был ли переоборудован участок Узунларского вала под противотанковый ров от обрыва на берегу Азовского моря и до железной дороги - а это расстояние около 4 км. На последний вопрос нет ответа, хотя на этом участке был трижды перерезан вал, но ни разу не был сделан разрез рва, что, на наш взгляд, намного важнее и информативнее.

Актуален вопрос датировки Савроматия - единственной крепости, стоящей в линии Узунларского вала. Не менее интересно, как заканчивался Узунларский вал в своей южной оконечности, а это 10 км территории. Об этом есть наши публикации, и у специалистов есть реальная возможность проверить наличие в этом районе валов Арины и Эльжбеты [Ермолин, 2019, с. 55, рис. 37-40]. А.А. Супренков упомянул вал Анастасии и поставил под сомнение существование как этого вала, так и других, найденных нами [Супренков, 2020, с. 360]. Что касается вала Анастасии, то он, безусловно, существует. А.А. Супренков при этом утверждает, что это противотанковый ров. Но доказательства этого утверждения, хотя бы фотография разреза, датирующий материал и, наконец, чертеж этого разреза отсутствуют. Данная им ссылка на архив не является доказательством.

И еще о вале Анастасии: в своей статье [Ермолин, 2019, с. 41] мы подробно описываем участок рва от городища Савроматий и до шоссе Феодосия - Керчь, и в этом описании указываем на рабочую версию о том, что в 1,35 км к западу от основного вала находился более ранний участок этого вала, названного нами валом Анастасии, но в дальнейшем при изучении доступного материала мы отказались от этой версии. Кстати, нигде в научных публикациях это название не упоминается, оно возникло лишь как рабочий вариант, поэтому обвинять нас в изобретении вымышленных рвов преждевременно. Мы всегда выдвигаем несколько предположений, параллельных версий при исследовании археологических объектов, и совершенно логично, что из этих версий со временем остается одна, наиболее рациональная и подтвержденная археологическим материалом и логикой. Однако этого нельзя сказать о нашем оппоненте - стороннике однозначных решений. Его «Ворота Боспора» претендуют на громкую сенсацию, но однозначные отождествления зачастую ошибочны. В действительности противотанковый ров 1941 г. сильно отличается от «Ворот Боспора» IV в. до н. э. Древний ров в этом месте был полностью уничтожен строительством противотанкового рва. Также показательна фраза: «... о хронологии «Боспорских Ворот» - каменного моста через Узунларский ров, открытых нами в 2016 г. к северо-западу от п. Горностаевка, писалось многократно» [Супренков, 2020, с. 365]; в ней очевидно стремление указать на признание своего предположения, но не открытия.

Что касается наших обоснований хронологии Узунларского вала, то мы пользуемся материалами, представленными в статьях А.А. Масленникова и отчасти А.А. Супренкова, а также на основании своих разведок и раскопок - как личных, так и в составе экспедиции КФ ИА НАНУ. В фотоматериалах об Узунларском вале, к сожалению, нет ничего, что доказывало бы версию нашего уважаемого оппонента [Супренков, 2020, рис. 1-3]; более того, на рис. 1 в линии Узунларского вала нет точки Т2, но на рис. 2-3 она появляется. Так где же находится эта точка Т2 (рис. 3)?

Далее в статье А.А. Супренкова описан вал Безкровного, где удивляет начало этого описания: «Работы же, проведённые на валу Безкровного, пока не дают возможности сколько-либо аргументированно говорить о его хронологии». Но раскопки вала Безкровного велись и до А.А. Супренкова. Видимо, публикации об этом остались ему недоступными. Между тем существует статья с подробным описанием как трассы вала, так и укреплений в его линии, которые буквально до десятилетия дают дату как этих укреплений, так и, соответственно, самого вала. По крайней мере, в списке литературы к работе А.А. Супренкова этой статьи нет [Ермолин, 2010, с. 130-161]. 


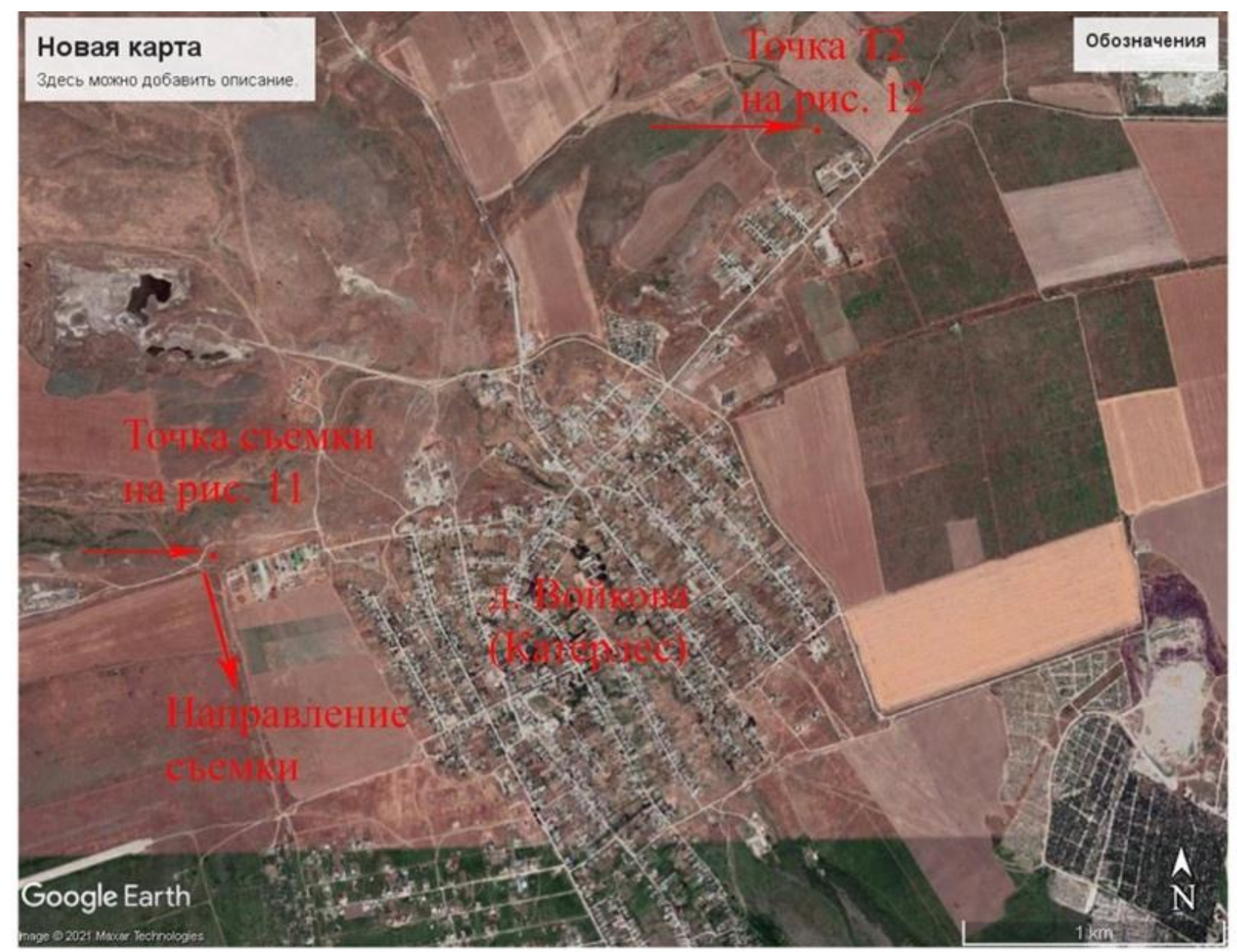

Рис. 3. Район д. Войкова (Катерлез), место фотосъемки Тиритакского вала на рис. 11, точка Т2 (по Супренкову)

Fig. 3. Region of the village of Voikova (Katerles), the place of photographing the Tiritaka swell in Fig. 11, point T2 (according to Suprenkov)

В дальнейшем нами был выявлен вал Татьяны, который является частью вала Безкровного, и об этом тоже есть статья [Ермолин, 2012, с. 25-33]. В статье о датировке валов [Ермолин, 2010, с. 130-131] высказана рабочая версия о продолжении вала после озера Тобечик. Есть и еще одна, пока не опубликованная версия, по которой вал заканчивается оврагом, который был в древности на месте современного озера. Как первый, так и второй вариант требует проверки, но если не будет найдено признаков вала от озера Тобечик до дер. Яковенково, значит, роль преграды - рва и вала - выполнял овраг. В результате разведок 2008 г. на южном стороне озера Тобечик нами были найдены остатки башни І в. до н. э. Есть большая вероятность того, что башня имела отношение к линии обороны, включавшей вал Безкровного.

Возвратимся к датировке вала Безкровного: он был построен, как и укрепления в его линии, в 60-х годах I в. до н. э. Изначально северная часть линии доходила до озера Чокрак и по оврагу доходила до Азовского моря. Через небольшой промежуток времени, буквально не больше года, строится новый участок вала, названного нами валом Татьяны. Этот участок вала прикрывал все Караларское побережье; в линии этого вала строится крепость - форт Артезиан, и западнее форта организуется проезд с башней [Ермолин, 2012 , с. 26]. Ранний участок вала Безкровного от вала Татьяны и до озера Чокрак частично засыпается и функциональной нагрузки уже не несет. А.А. Супренков исследовал вал Безкровного непосредственно у железнодорожного полотна, и для подтверждения или опро- 
вержения версии о наличии вала Татьяны ему нужно было сделать разрез этого вала, находящегося от места раскопок в 450 м к северу. По всей видимости, найти на местности этот вал оказалось затруднительно. Кроме того, при раскопках вала Безкровного, перед строительством трассы Таврида, участок вала, прилегающий к шоссе Феодосия - Керчь к югу от дороги, был практически уничтожен при его поиске с помощью землеройной техники, и только благодаря работам П.Г. Столяренко участок вала с севера был раскопан [Супренков и др. 2019а, с. 177-187; 2019б, с. 564-573].

При описании разведок северного участка вала Безкровного А.А. Супренков отмечает: «Тогда же был обследован северный участок этого вала к югу от озера Чокрак. Вал и ров здесь хорошо сохранились, а А.Л. Ермолиным ещё в 2008 г. была раскопана какая-то стена 3 (рис. 9)» [Супренков, 2020, с. 366]. Действительно, на рис. 9 изображен участок стены, раскопанной нами в 2008 г., но это не «какая-то стена», а стена в линии рва и вала на выходе скалы, где сложно было вырыть ров, так что вал и ров были заменены стеной из бутового камня. Об этой стене подробно сказано в статье о датировке валов [Ермолин, 2010 , с. 135 , рис. 5].

Особенно удивляет ссылка № 3 [Супренков, 2020, с. 366], где говорится: «К сожалению, научный отчёт А.Л. Ермолина за 2008 г. отсутствует как в архиве ВосточноКрымского музея-заповедника, так и в архиве ИА Крыма». С полной ответственностью следует заявить - это неправда. Наш отчет об этих разведках находится в архиве Керченского музея-заповедника, номер дела - оп. 2, ед. хр. 1888. Никаких заявок на работу с этим отчетом в музей не поступало, и это легко проверить.

Цитируем далее: «Участок же к югу от трассы «Таврида» и до Тобечикского озера пока не локализован и известен только по аэрофотоснимкам и архивным описаниям ...» [Супренков, 2020, с. 366]. Этот участок был исследован нашей экспедицией под моим личным руководством и участием в 2008 г., а все данные по этим разведкам опубликованы со схемами и фотографиями [Ермолин, 2010, с. 130-161]. Это ошибка или сознательное искажение?

Далее начинается заключительная часть статьи, где описывается Тиритакский вал. Автор не сомневается в том, что западный вал под названием Тиритакского, хорошо видимый на местности и отмеченный на всех картах, является самым поздним и датируется концом XVIII в. Об этом пишет и А.А. Масленников [Масленников, 2003, с. 164]. Не сомневались до последнего времени и мы, но решили еще раз обратиться к описанию раскопок этого вала у А.А. Масленникова. Ни обследования северных скатов гряды Золотого кургана от самого кургана и до Еврейской горки, ни поиски каких-либо следов на аэрофотоснимках 1941, 1954, 1976, 1994 годов не дали никаких результатов, кроме того, что следов какого-либо второго вала, кроме упомянутого Тиритакского, на снимках не было. Но А.А. Супренков пишет: «По мнению, устно высказанному Д.В. Бейлиным и основанному на данных аэрофотоснимка, ТВ 2 (или Катерлезский, по номенклатуре этого исследователя) завершается на юге в районе т. н. Еврейской горки (еврейское кладбище XVIII-XIX вв.)» [Супренков, 2020, с. 371].

То есть А.А. Супренков, как и подсказавший эту идею Д.В. Бейлин, считают, что ТВ 2 подходил к гряде в 1 км восточнее Золотого кургана. Вопрос: почему именно туда? Этот вал, отмеченный как ТВ 2, был построен в 60-х гг. I в. до н. э. В его линии находились крепости этого времени, и если смотреть с севера на юг, то у Азовского побережья в линии вала находится крепость Тархан, затем небольшая крепость Длинная Крепость (г. Михалкина), далее крепость на СЗ окраине дер. Войкова, следующей точкой к которой должен был подходить вал - укрепления на гряде с Золотым курганом. Допустим, что вал примыкал к Еврейской горке, но там не обнаружено никаких следов построек I в. до н. э., да и вообще даже следов древней застройки, зато непосредственно у Золотого кургана находилась крепость именно этого времени. В ходе археологических разведок в 2008-2009 гг. там были выявлены зольники с материалом I в. до н. э. - первых веков 
нашей эры. О строительных остатках и развалинах башен здесь писал еще П. Дюбрюкс [Дюбрюкс, 2010, рис. 447-470], и нет основания не доверять этим сведениям, тем более подтвержденных нашими разведками. Было бы вполне логично, если бы этот вал ТВ 2 подходил непосредственно к этой крепости, тем более что так наз. Золотой курган сам являлся крепостью, построенной еще в начале 2-й четв. III в. до н. э. [Ермолин, 2013, с. 12-23], и, естественно, эта крепость использовалась и в I в. до н. э.

В данный момент от подножья Золотого кургана (остатков крепости III в. до н. э.) начинается так называемый поздний Тиритакский вал. Этот вал дважды подвергался археологическому исследованию А.А. Масленниковым [Масленников, 2003, с. 164], а один разрез, сделанный им в 300 м южнее р. Мелек Чесме, заинтересовал нас, точнее, его подробное описание. Приведу заинтересовавшую нас часть этого обширного описания: «Стратиграфия вала и рва следующая (рис. 122). Вверху это очень тонкий (до 0,005-0,08 м) слой гумуса, лишь в области рва достигавший 0,35 м. Там же выделяется линза тёмного (чёрно-коричневого) умеренно рыхлого и влажного суглинка - заполнение рва. Длина ее 9,5 м, толщина 0,9 м. В верхнем горизонте этого слоя встречено несколько невыразительных обломков светло-глиняных амфор. Судя по структуре соседних участков, ров прорезал несколько слоев грунта. Первый - светло-коричневый (серо-коричневый), умеренно плотный и сухой суглинок, непосредственно подстилавший гумус. Толщина его на участке к западу ото рва $-0,45$ м, а в районе вала - до 0,6 м. Но здесь этот слой смотрелся в профиле траншеи как обращенная выпуклой стороной вверх линза длиной почти в 7 м. Далее к востоку этот слой исчезал. Над ним отчетливо прослеживалась тонкая прослойка рыхлого серого суглинка толщиной всего 0,05 м. По всей видимости, это и есть погребенная почва - прежняя дневная поверхность. Обращает на себя внимание то, что уровень залегания данной прослойки почти на 0,6 м выше района к западу ото рва, а в области вала её очертания напоминают линзу насыпи. Данное обстоятельство позволяет предположить, что либо естественный рельеф здесь имел повышение к востоку (что могло и определить выбор места при сооружении насыпи), либо эта прослойка хотя бы отчасти сформировалась за счёт аналогичного грунта, переотложенного при строительстве рва. В западной поле вала выделяется «полулинза» светло-серого рыхлого сухого суглинка. Длина ее 1,8 м, максимальная толщина (в восточной части) 0,4 м. Длинный «затек» такого же грунта присутствовал и в профиле восточной полы вала. Наибольшая его толщина составляла $0,4-0,44$ м. Ни к западу ото рва, ни к востоку от соответствующей полы вала этот слой не выявлен. Уровень его залегания в последнем случае явно понижался. Попутно заметим, что именно тут, на глубине 0,2-0,45 м от современной дневной поверхности, были найдены мелкие обломки железных гвоздей и дно толстостенной стеклянной винной бутылки. Особенности её формы и состава стекла характерны для посуды такого рода, выпускавшейся в конце XVIII первой половине XIX вв. Но откуда брался описанный грунт, не вполне ясно» [Масленников, 2003, с. 175].

А теперь предположим, что участок древнего т. н. Тиритакского вала проходил в этом месте, и позже по нему был прокопан вал в конце XVIII в. (ситуация такая же, как в районе т. н. «Ворот Боспора», где участок Узунларского вала был перестроен в противотанковый ров). Тогда становится понятно и наличие небольшой возвышенности под валом, перекрытой слоем серого суглинка - дернового слоя на древнем валу, и перекрывающие его полулинзы серого суглинка с материалом конца XVIII в. - они являются верхним слоем заполнения древнего рва с мусором конца XVIII в. Все встало на место найден участок древнего вала и выяснены загадки стратиграфии. Вывод здесь один: изначальный ров и вал проходили непосредственно от Золотого кургана и до реки Мелек Чесме, далее ров смещался на 300 м к В и проходил уже по полю в сторону крепости у дер. Войкова. В 453 г. ров и вал восстанавливаются по этому древнему рву и валу, что видно из наших раскопок 2008 г. Далее, в конце XVIII в. строится оборонительная линия, где 
часть ее от Золотого кургана и до р. Мелек Чесме проходит по древнему рву, а северный участок строится заново. Раскопки, проведенные А.А. Масленниковым на северном участке вала, не подтвердили стратиграфию южного участка [Масленников, 2003, c. 176-177].

Далее А.А. Супренков рассказывает об археологических разведках севернее д. Войкова и ссылается на иллюстрации: на рис. 12 схематично указаны точки Т1 и Т2, где были проведены разведки и собран археологический материал, далее на рис. 11 показано, где именно проводились разведки в точке Т2. Подпись под рис. 11 гласит: «Тиритакский вал. Съемка в точке Т2, вид с севера». Но на рисунке мы видим северный участок Тиритакского вала от Золотого кургана и до Катерлесской гряды. Снимок сделан с высоты на этой гряде в сторону вала. Точка Т2, заявленная на рис. 12, находится в 3 км к СВ от этого места (рис. 3, 4) [Супренков, 2020, рис. 11, 12]. С Т2 вообще не видно никаких валов, а что касается сбора подъемного материала, то в этом месте еще В.В. Веселовым были разведаны поселения 92/74.-5 и 93/75.-6, датируемые поздней бронзой - IV в. до н. э. [Веселов, 2005, c. 28-29].

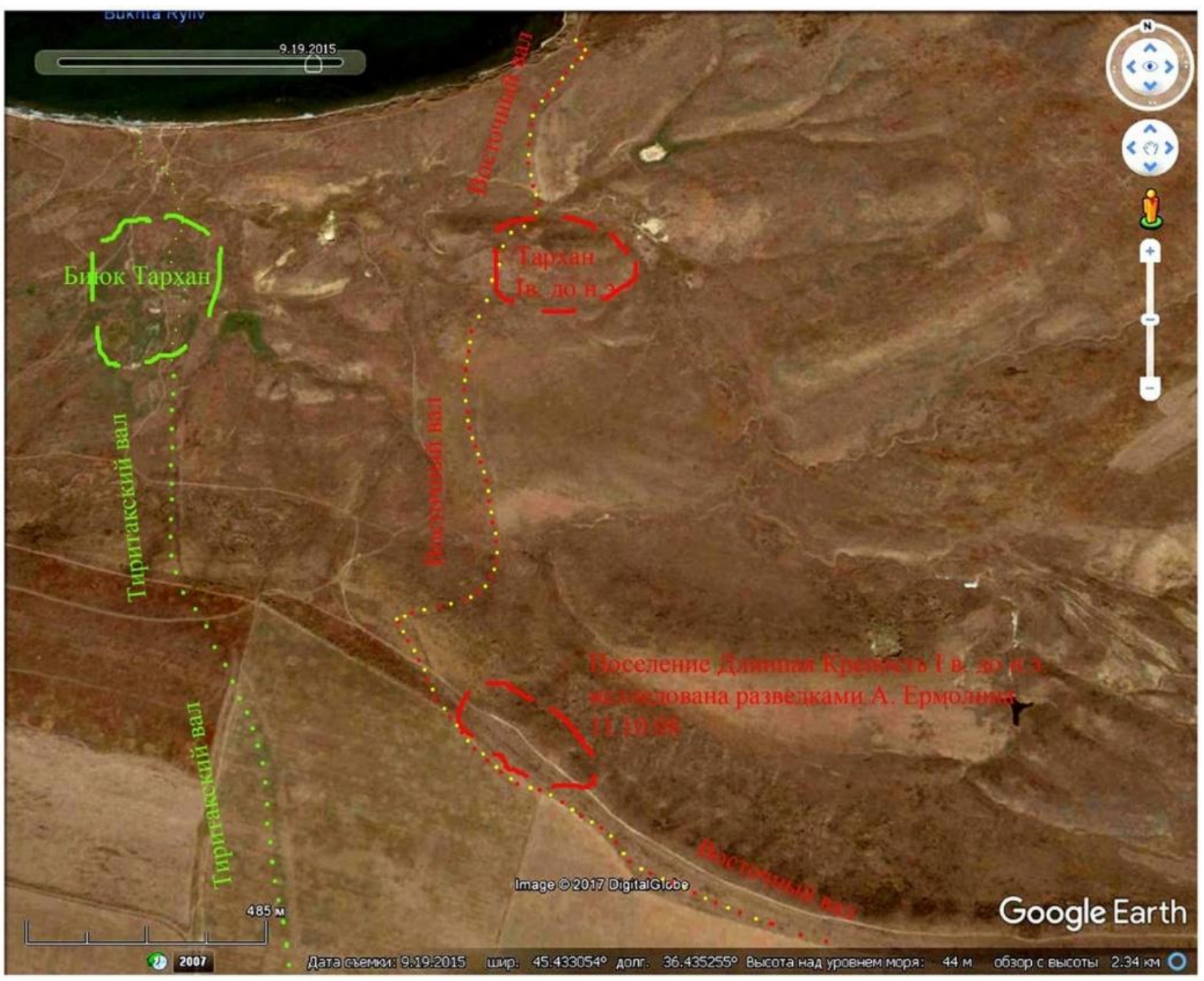

Рис. 4. Снимок ГУГЛ. Северный участок Восточного вала и Тиритакского вала.

В линии Восточного вала на этом участке находятся два укрепленных поселения начала I в. «Тархан» и «Длинная Крепость». Красным обозначен Восточный вал, зеленым - Тиритакский вал

Fig. 4. A snapshot of the GUGL. Northern section of the Eastern Wall and the Tiritak Wall.

In the line of the Eastern Wall on this site there are two fortified settlements of the beginning of the 1st century. «Tarkhan» and «Long Fortress». The East Rampart is red, the Tiritaka Rampart is green 
Тиритакский вал ТВ 2 (по Масленникову) находится вообще не там, а в 3 км к Ю3 от этого места, между Золотым курганом и Катерлесской грядой, а в 300 м к С3 находится вал и ров Восточной линии обороны или Тиритакский вал по Гриневичу [Гриневич, 1946, c. 160-164]. При всем уважении к К.Э. Гриневичу, этот вал не имеет никакого отношения к Тиритакскому валу, идущему в сторону Тиритаки, и прослежен им не до конца, а на протяжении 5 км к СВ-С3 от д. Войкова (Катерлез) до небольшой крепостицы «Длинная крепость», далее он наткнулся на Третий Тиритакский вал (ТВ3) (по Масленникову), который шел в сторону д. Тархан (Биюк Тархан) (рис. 5). Именно эта трасса Тиритакского вала нарисована и у А.А. Супренкова [Супренков, 2020, с. 361, рис. 1]. А.А. Супренков просто воспроизвел северную часть т. н. Тиритакского вала по схеме К.Э. Гриневича, не разобравшись с истинным положением как Восточной линии обороны, так и Тиритакского вала, а это два совершенно разных сооружения, хотя их трасса совпадает на довольно большом участке.

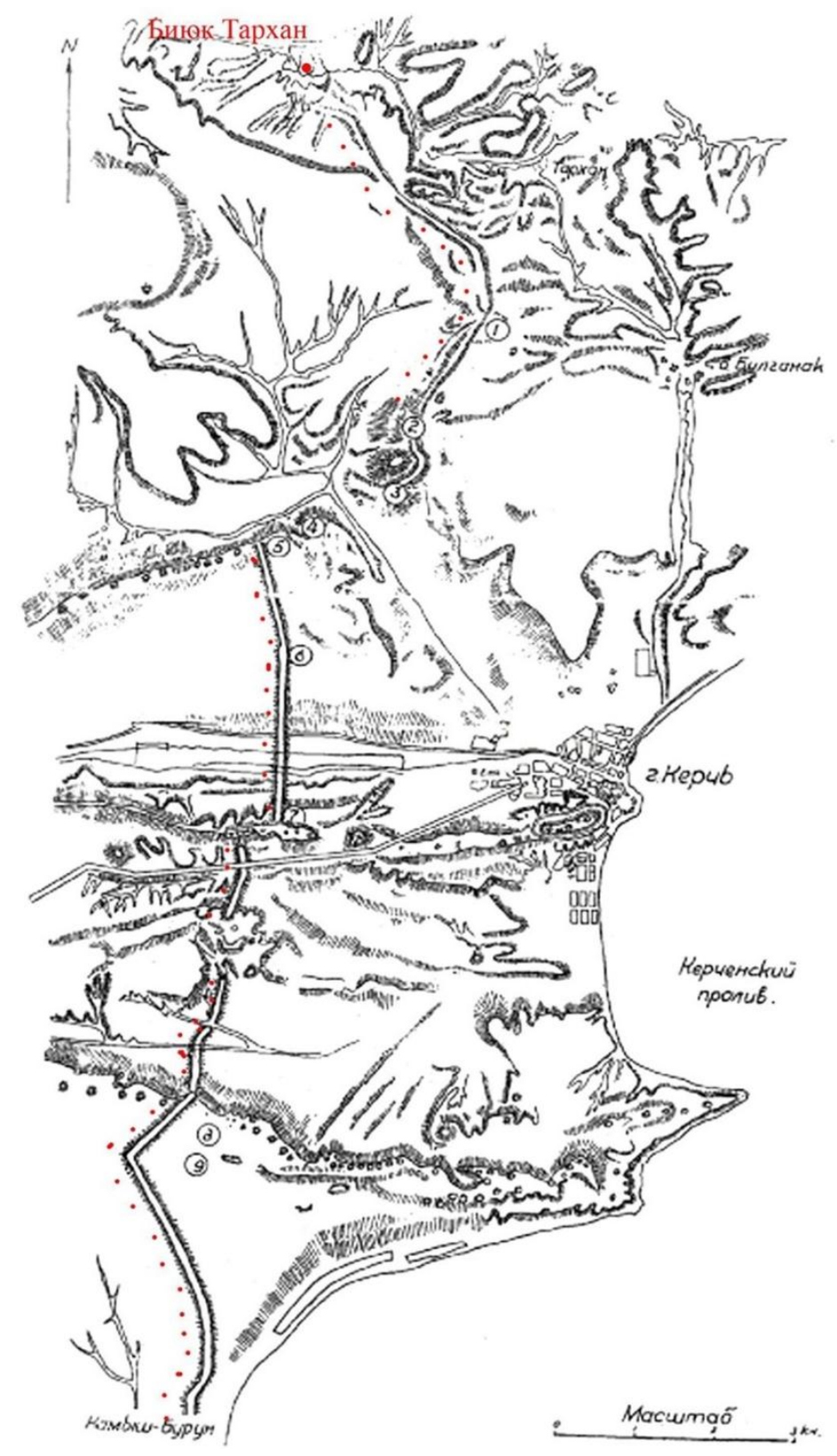

Рис. 5. Схема Тиритакского вала по К. Гриневичу, разведки 1924-1925 гг. Для наглядности трасса вала усилена красными точками

Fig. 5. Scheme of the Tiritaka shaft according to K. Grinevich, reconnaissance 1924-1925. For clarity, the shaft route is reinforced with red dots 
Заканчивается описание Тирикакского вала у А.А. Супренкова следующим образом: «Исследованный нами вал у с. Войково далее следует к северо-востоку в сторону Азовского побережья мимо (к западу) горы Михалкина в сторону мыса Тархан. На этом участке А.А. Масленниковым был в своё время заложен стратиграфический разрез [Масленников, 2003, с. 128], давший невыразительный археологический материал».

Здесь речь идет о том, что вал должен заканчиваться на м. Тархан, но на рис. 1 у А.А. Супренкова он почему-то заканчивается у бывшей деревни Тархан (Тархан Биюк), а это разные объекты. И А.А. Масленников делал стратиграфический разрез на Тиритакском валу (Тиритакский ров 3), а не на Восточной линии обороны, которая действительно заканчивается на мысе Тархан.

Восточный вал (Восточная линия обороны) начинается у берега Азовского моря немного западнее мыса Тархан и проходит по гряде в направлении СЮ (рис. 4, 6-7), огибает с севера поселение I в до н. э. «Тархан» (рис. 4, 6-7), затем по складкам местности идет в направлении поселения «Длинная Крепость» I в. до н. э. (рис. 4, 8), расположенного на горе Михалкина (совр. название), огибает гору и по гряде в направлении ЮВВ проходит около 800 м (рис. 4, 7).

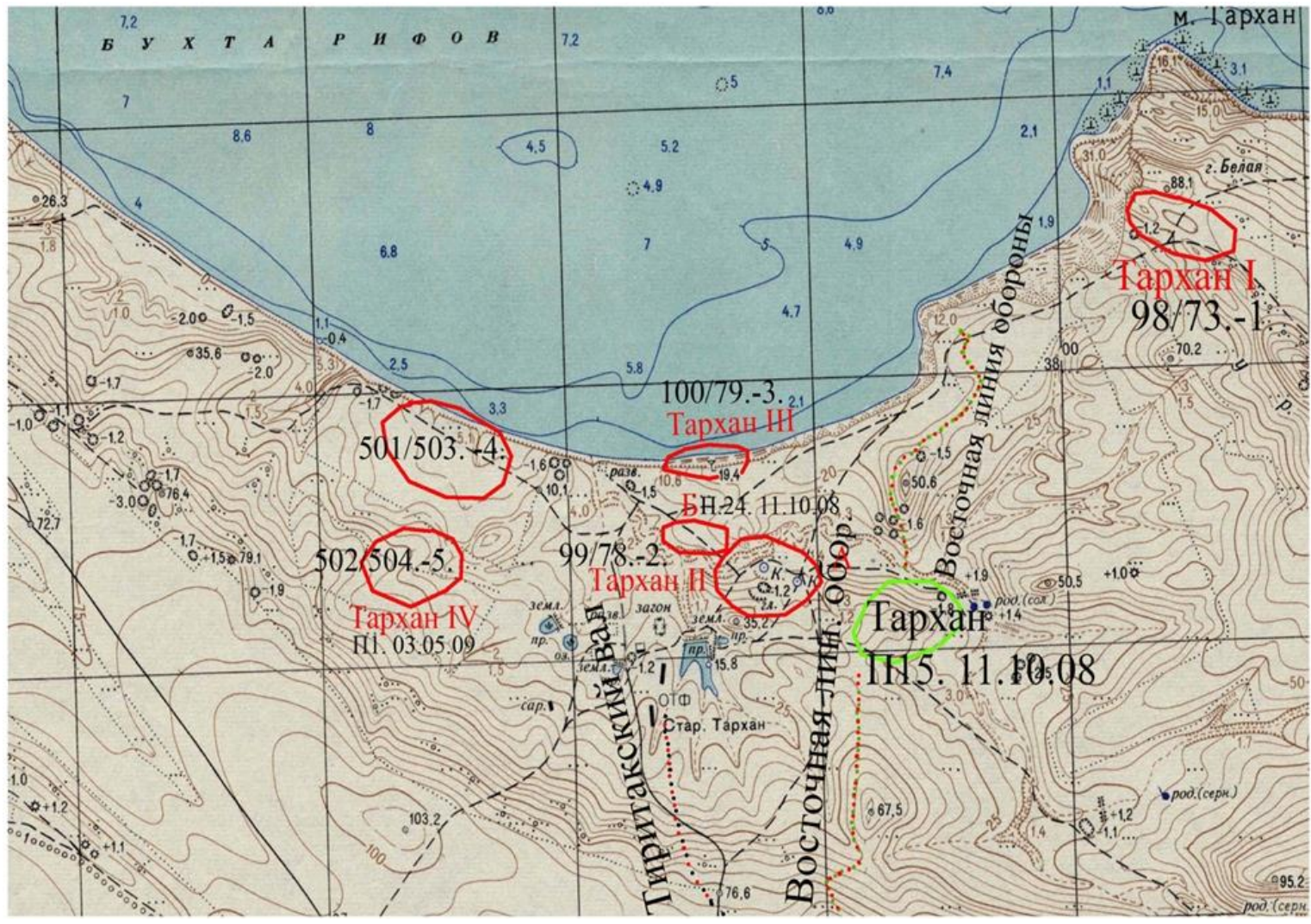

Рис. 6. Район бывшей дер. Тархан (Биюк Тархан) с поселениями, разведанными В.В. Веселовым, И.Т. Кругликовой и А.Л. Ермолиным. Красным отмечены поселения по Веселову и Кругликовой, зеленым - по Ермолину, красными и зелеными точками отмечена трасса Восточной линии обороны, красными и черными точками отмечен Тиритакский вал (валы по Ермолину). Надписи - черными цифрами - по Веселову, красными - по Кругликовой. Номер пункта и дата (П15. 11.10.08) - номер выявленного объекта и дата разведки по Ермолину

Fig. 6. The area of the former village. Tarkhan (Biyuk Tarkhan) with settlements explored by V.V. Veselov, I.T. Kruglikova and A.L. Ermolin. The settlements along Veselov and Kruglikova are marked in red, the settlements along Ermolin are green, red and green dots are used to mark the route of the Eastern line of defense, the Tiritaksky shaft (walls along Ermolinnu) is marked with red and black dots. The inscriptions are in black numbers according to Veselov, red according to Kruglikova. Item number and date (P15. 11.10.08) - the number of the identified object and the date of exploration at Ermolin 


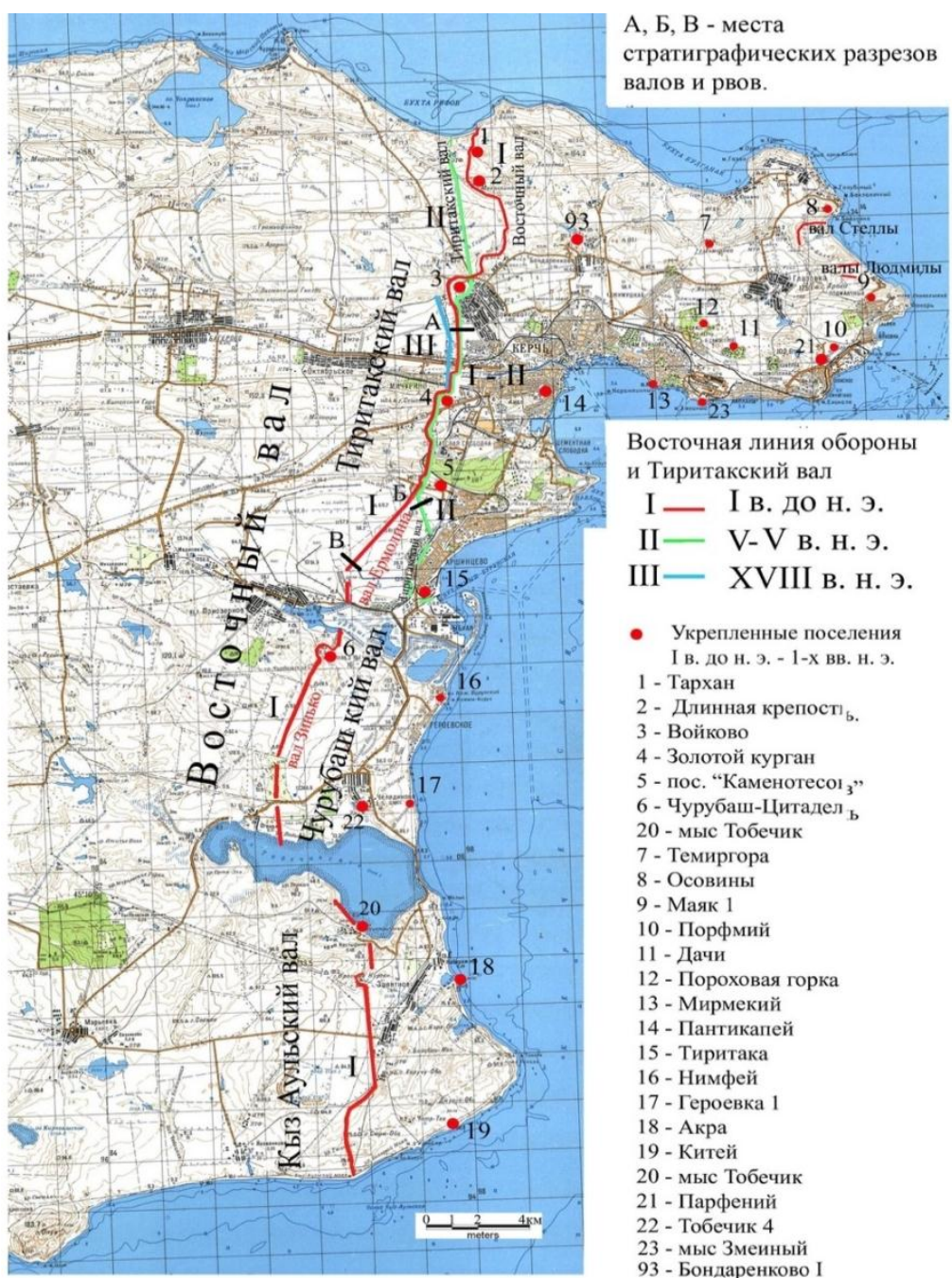

Рис. 7. Ситуационный план местоположения Восточной линии обороны и укрепленных поселений І в. до н. э., расположенных в линии вала и восточнее вала

Fig. 7. Situational plan for the location of the Eastern line of defense and fortified settlements of the 1st c. B. C., located in the line of the rampart and east of the rampart

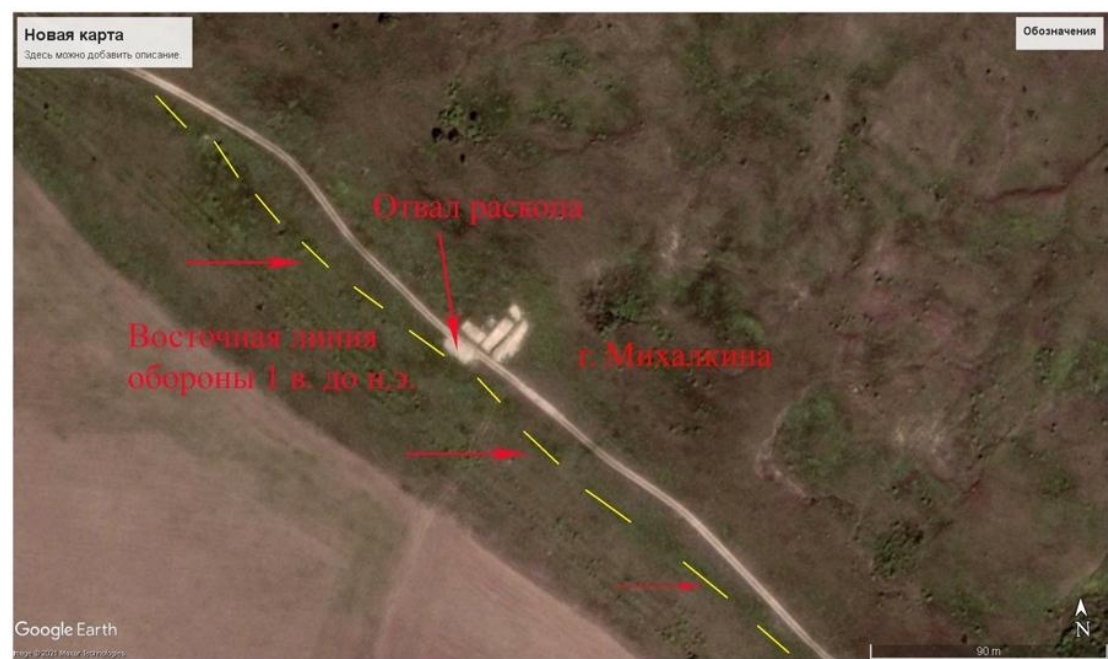

Рис. 8. Трасса Восточной линии обороны на г. Михилкина, где расположена «Длинная Крепость» І в. до н. э.

Fig. 8. The route of the Eastern line of defense to the town of Mikhilkina, where the «Long Fortress» of the 1 st century B. C. is located 
За горой Михалкина вал поворачивает в направлении ЮВ и дугой по полю выходит на Катерлезскую гряду, там в направлении ЮЮЗ по складкам местности доходит до поселения I в. до н. э. Войково І. При обследовании поселения Войково I 11.10.2008 были выявлены следы рва с северной и западной стороны. Велика вероятность того, что вал огибал поселение с севера и запада и юго-востока (рис. 7), далее шел строго на юг в направлении Золотого кургана. Далее доходит до р. Мелек Чесме и через 300 м к западу продолжается по хорошо видимому Тиритакскому валу (по Масленникову) до Золотого кургана (описание выше) (рис. 9).

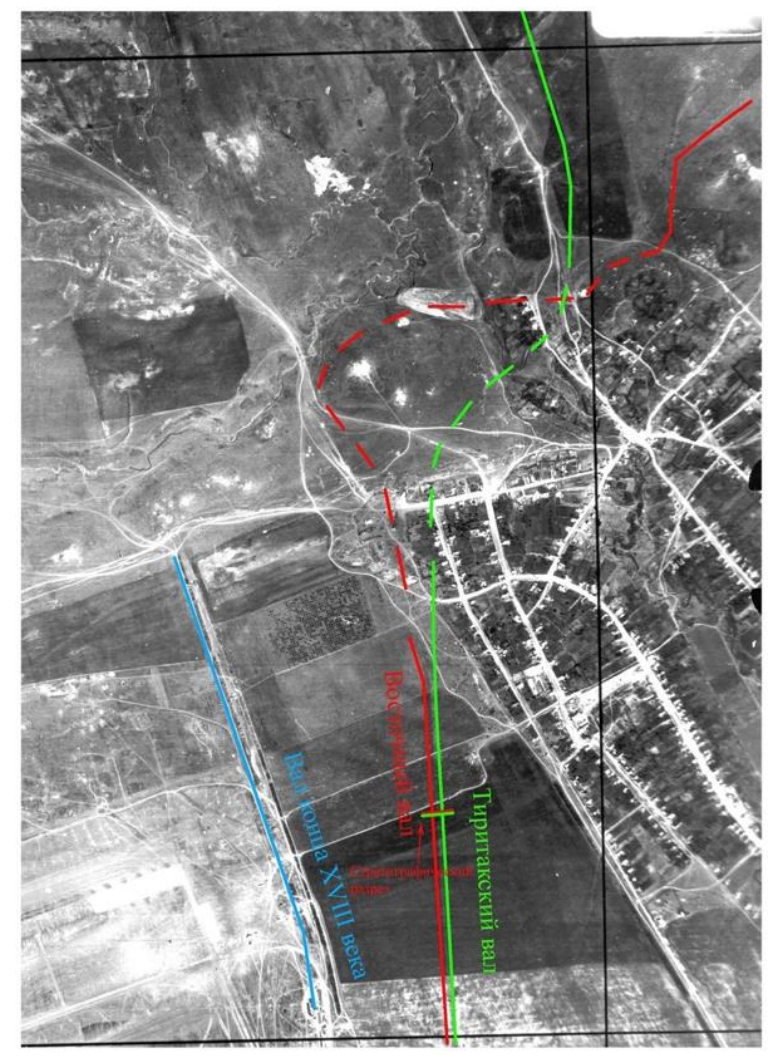

Рис. 9. Аэрофотосъемка 1954 года. Валы Тиритакский, восточный и вал конца XVIII в.

Тиритакский и Восточный валы западнее д. Войкова проходят «два в одном». Штрихами обозначны предполагаемые трассы валов

Fig. 9. Aerial photography of 1954. Ramparts of Tyritaksky, eastern and ramparts of the end of the 18th century. The Tiritak and Vostochny ramparts to the west of the village of Voikova are two-in-one. The dashed lines indicate the proposed shaft routes

Здесь стоит сделать небольшое отступление и вернуться к памятнику археологии крепости «Тархан». Название этому памятнику дано при его обследовании еще в 2008 г. Керченской охранно-археологической экспедицией под нашим руководством.

В 2015 г. вышла статья Д.В. Бейлина [Бейлин, 2015, с. 19-28], где говорится, что в ходе разведок им (Бейлиным) найдено поселение в районе бывшего поселка Биюк Тархан и названо «Тархан І». Необходимо уточнить названия археологических памятников, а также их первооткрывателей.

Название «Тархан І» встречаем у И.Т. Кругликовой [Кругликова, 1975, табл. 59] «Тархан I - около 2 км к северо-востоку от кошар».

У В.В. Веселова [Веселов, 2005, с. 31] это же поселение значится под номером 98/77.-1 и описывается следующим образом: «Примерно в 2 км северо-восточнее кошар (быв. Тархан), в 0,25 км от морского берега, в небольшой лощине встречено значительное скопление фрагментов древней посуды. В откосе берега веден культурный слой. При осмотре территории подняты следующие археологические предметы: амфорные ручки, 
овальные в поперечном сечении; ножки гераклейских амфор; ножки амфор с широкими пятками (рис. 28, рис. 29); уширенный венчик кухонной лепной посуды (рис. 30); обломки пантикапейских кровельных черепиц. По-видимому, здесь было небольшое поселение эллинистического времени. Территория распространения фрагментов посуды примерно равна 1,5-2,0 га».

И действительно, в 2009 г. Д.В. Бейлиным было обследовано поселение в лощине, примерно в 2,3 км к СВ от развалин фермы на месте бывшей дер. Тархан, примерно в 0,25 км от береговой линии. Подъемный материал представлен был в основном керамикой поздней бронзы, но масштабных разведок и шурфовок в то время проведено не было. Еще раз 13.11.2009 этот памятник посещался нами совместно с С.Л. Смекаловым. Этот памятник отмечен им на Археологической карте Крыма на горе Белая как поселение эпохи бронзы. Мы уверены, что при тщательной разведке здесь будет выявлена и эллинистическая керамика, упомянутая В.В. Веселовым, и именно это поселение упоминал В.В. Веселов под № 98/77.-1, а И.Т. Кругликова под названием «Тархан І». Разница в 300 м здесь вполне объяснима, мы не знаем откуда измерялось расстояние, да и измерения были указаны «примерно». Мы считаем, что именно это поселение и есть «Тархан І».

Поселение, описанное Д.В. Бейлиным, было впервые официально обследовано экспедицией КОАЭ под моим руководством 11 октября 2008 г. В разведках в этот день принимали участие: А.Л. Ермолин - начальник экспедиции, С.А. Ермолин - лаборант КФ ИА НАНУ, А.В. Куликов - мл. н. сотрудник КФ ИА НАНУ, С.Ю. Бейлина - лаборант КФ ИА НАНУ и Д.В. Бейлин - мл. н. сотрудник КФ ИА НАНУ. Экспедиция была организована лично мной и под мой Открытый Лист. Задачей разведок было выявление трассы Тиритакского вала (рабочее название) в северной его части и археологических объектов в системе вала, а также обследование района быв. дер. Тархан. В ходе разведок была найдена трасса вала, начиная от поселения в дер. Войкова (Катерлез) и до Азовского побережья. Не доходя до берега Азовского моря около 700 м, в линии исследуемого вала были выявлены следы поселения, а в грабительской яме собрана керамика I в. до н. э. - I в. н. э. Выявленное поселение было названо мною «Тархан». Это поселение было обследовано 11.10.2008 и в полевом дневнике обозначено как пункт № 15. Координаты поселения: $45.440441^{\circ} ; 36.433689^{\circ}$.

Еще можно добавить, что пункты, отмеченные С.Л. Смекаловым на Археологической карте Крыма ${ }^{36}$ в районе бывшей дер. Тархан, предоставлены мною и являются результатом разведок 11.10.2008 г. Изучив всю доступную археологическую литературу, касающуюся разведок и раскопок района дер. Тархан, можно утверждать, что нигде не упоминается поселение, расположенное в 1 км к С33 от ОТФ в бывшей дер. Тархан. Можно также с уверенностью сказать, что участок вала от горы Михалкина (Длинная Крепость) и к северу до Азовского побережья также выявлен именно этими разведками 11.10.2008. В дальнейшем нами было установлено, что этот участок вала, проходящий через поселение «Тархан», не является северной оконечностью Тиритакского вала, а относится к Восточной линии обороны, датируемой нами началом I в. до н. э. - временем Митридата VI Евпатора. В статье «Тиритакский вал - элемент Восточной линии обороны» ${ }^{37}$ подробно описывается эта оборонительная система и там же под № 1 значится поселение «Тархан». Что касается авторства открытия поселения «Тархан», Д.В. Бейлин в тот день (11.10.2008) говорил, что этот памятник он впервые посещал ранее вместе с членами краеведческого клуба «Ларус» под руководством Б.И. Бабича, так что я считаю, что автором открытия следует считать именно Б.И. Бабича, а так как памятник официально был исследован Керченской охранно-археологической экспедицией, то название «Тархан» считать единственно верным и законным.

\footnotetext{
${ }^{36} \mathrm{http} / / / \mathrm{www} . \operatorname{archmap} . \mathrm{ru} / 85 . \mathrm{htm}$.

${ }^{37} \mathrm{http}: / /$ kukiit.ru/docs/ts/no4/8.pdf.
} 
Теперь о Тиритакском вале. Тиритакский вал (вал № 3 по А.А. Масленникову) начинается на территории бывшего пос. Биюк Тархан в 1 км от побережья Азовского моря и является продолжением оврага - небольшой речки, впадающей в Азовское море (рис. 2, 4, 6-7). Этот километр оврага более непроходим, чем сам ров, и смысла вести ров до самого побережья в этом месте не было. Подобная ситуация характерна для поздних валов, например, вала Елены (рис. 2), но и в валах I в. до н. э. на второстепенных участках подобные замещения встречаются. Далее ров идет практически в южном направлении с небольшим смещением к востоку до северной окраины дер. Войкова (Катерлез). Судя по тому, что он довольно далеко заходит в саму деревню, есть большая вероятность того, что он не шел вокруг поселения «Войково I», да и само поселение уже не существовало в V в. н. э. В 600 м южнее поселения Тиритакский вал был проложен по более раннему рву - Восточному валу (рис. 9). На западной окраине дер. Войкова в 2008 г. был сделан стратиграфический разрез (рис. 9), который показал, что ров имеет две стадии строительства, притом между первым и вторым этапом ров был почти заполнен, и второй ров практически копался заново, но здесь сыграл роль тот фактор, что сам вал сохранился неплохо и при восстановлении рва вал значительно увеличивался в размерах.

По неизвестной причине А.А. Супренков отчитывается моим чертежом этого разреза в своей статье, а это значит, разрез этого рва А.А. Супренков сделал не в районе ж/д станции, а непосредственно у моего разреза, каких-либо доказательств в виде фотографий он в статье не дает, а тот снимок, что есть в статье, можно сделать где угодно, там даже самого рва не видно. Довольно странно описание этого разреза: «Новый разрез на Тиритакском валу № 2 был заложен южнее упомянутого разреза А.Л. Ермолина, непосредственно к северу от железной дороги (рис. 15). В процессе работ была выявлена западная часть рва до его дна, восточная осталась недообследованной вследствие ограничений данного земельного отвода (после обнаружения дна рва на глубине около 2,5 м от его устья работы были приостановлены и объект законсервирован). Любопытен археологический материал, найденный в его заполнении (рис. 18, 3-5). Он представлен ручками хиосской амфоры эллинистического времени и гераклейской амфоры I в. до н. э. - I в. н. э.» [Супренков, 2020, с. 370-371, рис. 15].

Из всего этого становится очевидно, что ров в действительности не был исследован. Если бы были представлены реальные снимки этого вала, где можно установить его местоположение, то ситуация была бы иной. Но таких снимков нет, иначе они бы были в статье, как нет и самого чертежа этого разреза у железной дороги.

Об археологическом материале из этого шурфа и датировках: Тиритакский, как и Узунларский валы А.А. Супренков датирует опять-таки по одиночным находкам керамики, которые не имеют никакого отношения к этому сооружению, тем более что последнее восстановление рва и вала (уже Тиритакского) было в V в., а Восточная линия обороны, по которой был вторично проложен Тиритакский вал, датируется 60-ми гг. I в. до н. э.

Итак, Восточная линия и Тиритакский вал, уже «два в одном», доходят до реки Мелек-Чесме, далее их линия смещается на 300 м к западу по реке и идет уже как «три в одном» до Золотого кургана (рис. 10).

В описании А.А. Супренковым т. н. Тиритакского вала, его северного участка, есть фраза в сноске: «4. Автор выражает благодарность исследователям И.В. Рукавишниковой и Д.В. Бейлину за консультации и доступ к материалу». У нас сложилось мнение, что Д.Б. Бейлин вместе с И.В. Рукавишниковой тоже не досконально разобрались в ситуации с валами.

Оканчивается статья таким образом: «Наконец, попытаемся рассмотреть ситуацию с участком Тиритакского вала южнее Юз-Обинской гряды (ТВ 1). На сегодняшний день нигде к югу от Второго Змеиного кургана насыпь идентифицировать не удалось», - правда это не самый конец, заканчивается статья сомнениями в существовании Восточной линии обороны. 


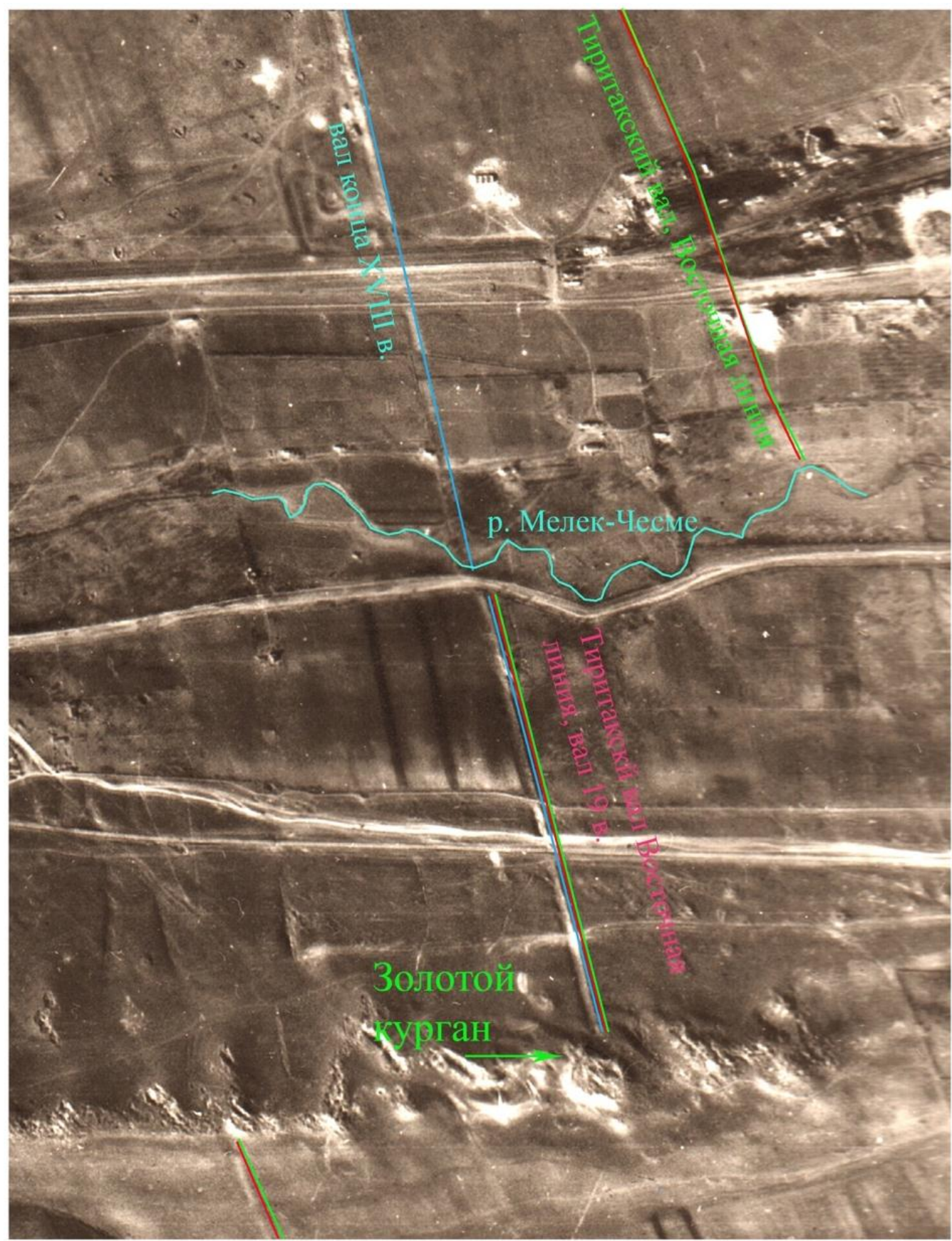

Рис. 10. Аэрофотосъемка 1941 года. Валы Тиритакский, Восточный и вал конца XVIII в. севернее Золотого кургана

Fig. 10. Aerial photography of 1941. Ramparts Tyritaksky, Vostochny and ramparts of the end of the 18th century north of the Golden Barrow

Здесь непонятны утверждения о том, что южнее Большого Змеиного кургана не удалось найти линию Тиритакского вала, хотя она совершенно четко обозначена на местности как валом, так и рвом. Скорее всего, автор статьи там просто не был, а удовлетворился иллюстрациями, представленными ему неким А.М. Михайловым. Кстати, кто такой А.М. Михайлов и какое отношение он имеет к валам Боспора, осталось неизвестным. Что касается этих иллюстраций и гипотетической трассы окончания вала на рисунках Михайлова, то это говорит в первую очередь о том, что он не знаком с топографией этого района. На рис. 16 в статье А.А. Супренкова совершенно неверно обозначен Тиритакский вал, точнее, его окончание на карте масштаба 1:25 тыс. Здесь перепутан поворот железнодо- 
рожного полотна на карте со старой дорогой на верстовке. В самом деле, на современной карте вал заканчивается непосредственно у ЮЗ угла стадиона. Кстати, это хорошо видно на рис. 17 этой же статьи [Супренков, 2020, рис. 16-17].

Теперь о Тиритакском вале южнее Большого Змеиного кургана. За Вторым Змеиным курганом, южнее него, трасса Восточного и Тиритакского вала поворачивает на ЮЗ, часть рва и вал на протяжении около 400 м уничтожены карьером, но за карьером на протяжении 200 м вал хорошо просматривается как на снимках Гугл, так и на местности (рис. 11).

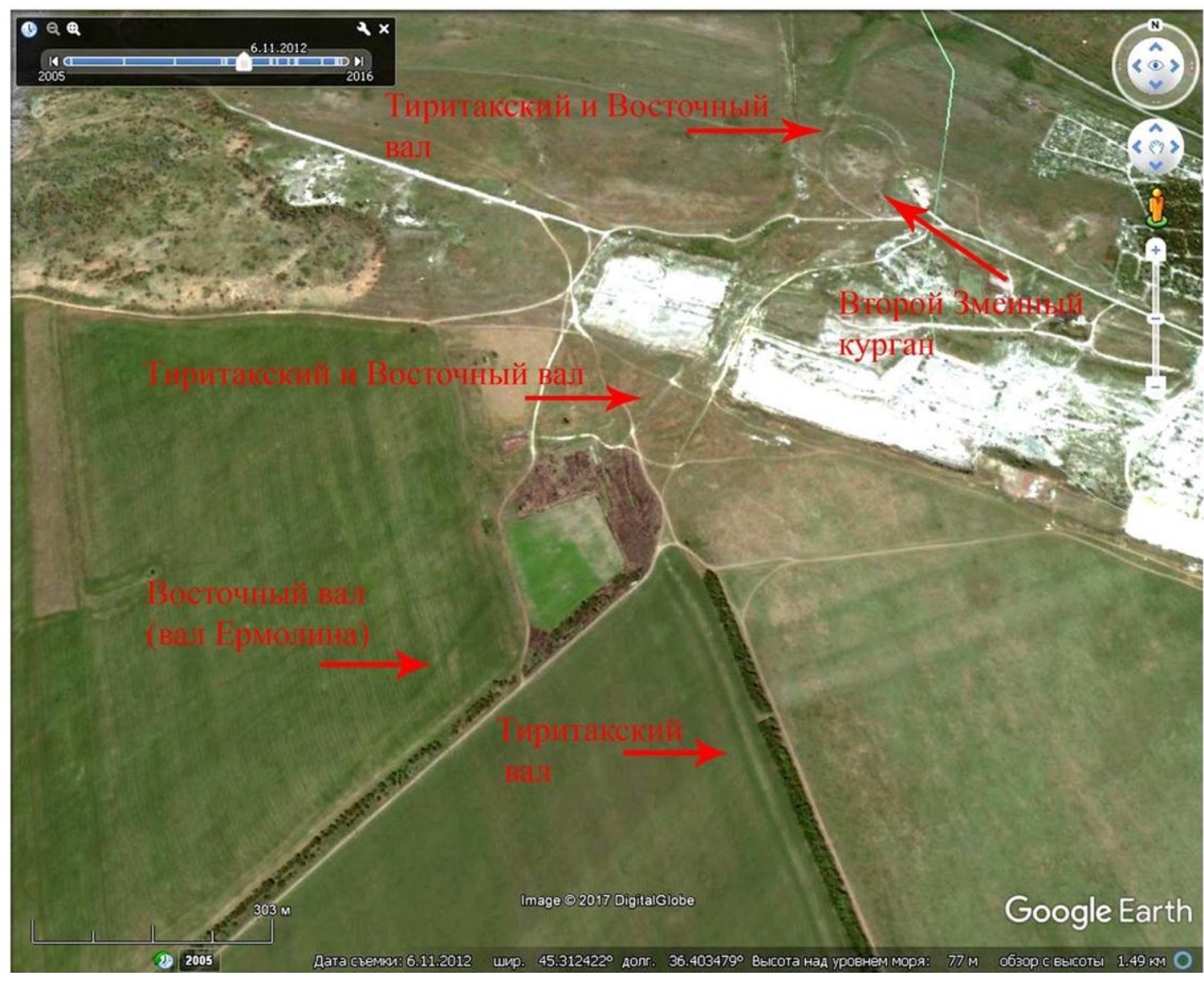

Рис. 11. Космическая съемка 11.20.12. Трасса Тиритакского и Восточного валов южнее Второго

Змеиного кургана. В 630 м южнее Второго Змеиного кургана трассы Восточного вала и

Тиритакского вал расходятся. Участок Восточного вала от развилки и до бывш.

дер. Александровки найден мною в ходе разведок 31.03.09 и назван «вал Ермолина». Этот участок является составной частью Восточного вала

Fig. 11. Space imagery 11.20.12. The route of the Tiritak and Eastern ramparts to the south of the Second Serpent Barrow. 630 m south of the Second Serpent Barrow, the routes of the Eastern Wall and the Tiritak Wall diverge. Section of the Eastern Wall from the fork to the former. village Aleksandrovka was found by me during reconnaissance on 03/31/2009 and named «Ermolin shaft». This site is an integral part of the Eastern Rampart

На окончании этого 200-метрового сохранившегося отрезка или в 600 м от Второго Змеиного кургана трасса Тиритакского вала отходит от общей трассы Восточного и Тиритакского вала и уходит на север в сторону быв. пос. Камыш Бурун (рис. 11-12). Восточный вал, не меняя направления, уходит в сторону быв. дер. Александровка (рис. 11).

Ответвляясь от общего рва и вала (Восточного и Тиритакского № 1 по А.А. Масленникову) в 600 м Ю3 Второго Змеиного кургана, трасса Тиритакского вала уходит практически на юг в сторону быв. пос. Камыш-Бурун (рис. 11-13) и доходит до оврага в 2 км севернее. Далее ров не был прослежен ни топографами конца XIX века, ни разведками 
К. Гриневича 1924-1925 гг., ни более поздними разведками В.В. Веселова. Дальнейшие разведки не имели даже смысла, т. к. вся территория вплоть до Тиритаки была застроена. Только в 2004 г. в ходе наблюдений за прокладкой газопровода вдоль Тиритаки удалось проследить стратиграфию в борту траншеи в 50 м к северу от стен Тиритаки. Никаких признаков рва в траншее газопровода на протяжении 1,5 км как от самой Тиритаки с запада, так и непосредственно у городища выявлено не было. Если бы ров доходил до самой Тиритаки, то траншея газопровода его бы точно пересекла.

Из всего вышесказанного можно сделать вывод, что Тиритакский ров в южной своей оконечности заканчивался оврагом, проходящим с севера от ЮВ угла стадиона в Аршинцево и на юг мимо Тиритаки до оз. Чурубаш (рис. 12).

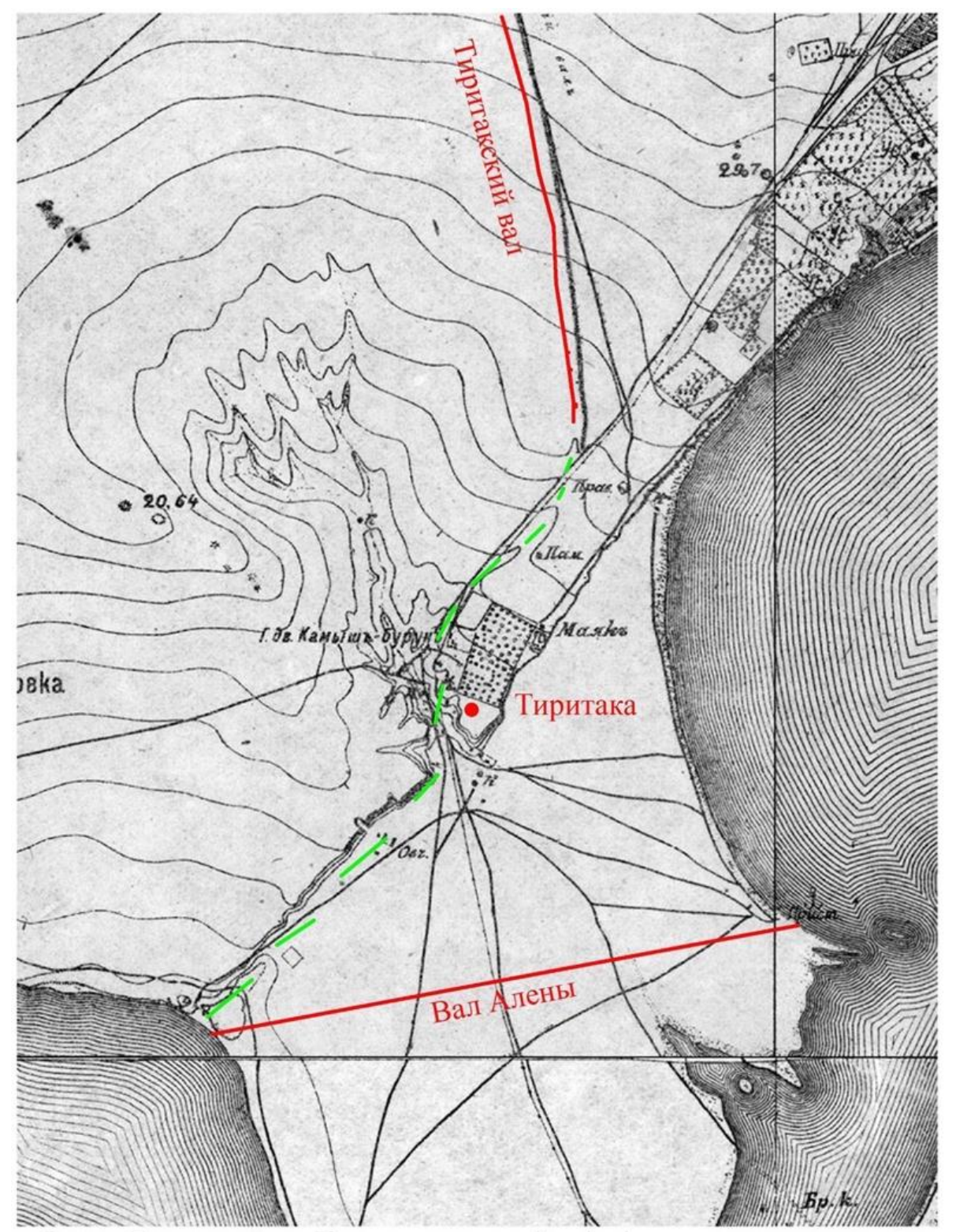

Рис. 12. Тиритакский вал. Южная оконечность. Вал (ров) заканчивается оврагом, далее зеленым цветом обозначены естественные препятствия - овраг и обрыв. Южный фланг района Тиритаки прикрывался валом «Алены» в дефиле между оз. Чурубаш и Керченским проливом. Карта «верстовка» 1894 г.

Fig. 12. Tyritaksky shaft. South end. The shaft (moat) ends in a ravine, then natural obstacles are indicated in green - a ravine and a precipice. The southern flank of the Tiritaki area was covered by the «Alena» rampart in the defile between the lake. Churubash and the Kerch Strait. Map «layout» 1894 
Овраг являлся продолжением рва, как это было и на северной его оконечности в быв. ауле Биюк Тархан. Но в такой ситуации южный фланг городища Тиритака остается незащищенным, и здесь мы находим еще один вал - вал Алены, расположенный в дефиле между Чурубашским озером и Керченским проливом (рис. 12-13). Об этом вале сказано в более ранней публикации в фейсбуке «Археологические открытия Alex Ermolin» ${ }^{38}$. Именно вал Алены логично завершает так называемый Тиритакский вал, а точнее - Тиритакскую линию обороны.

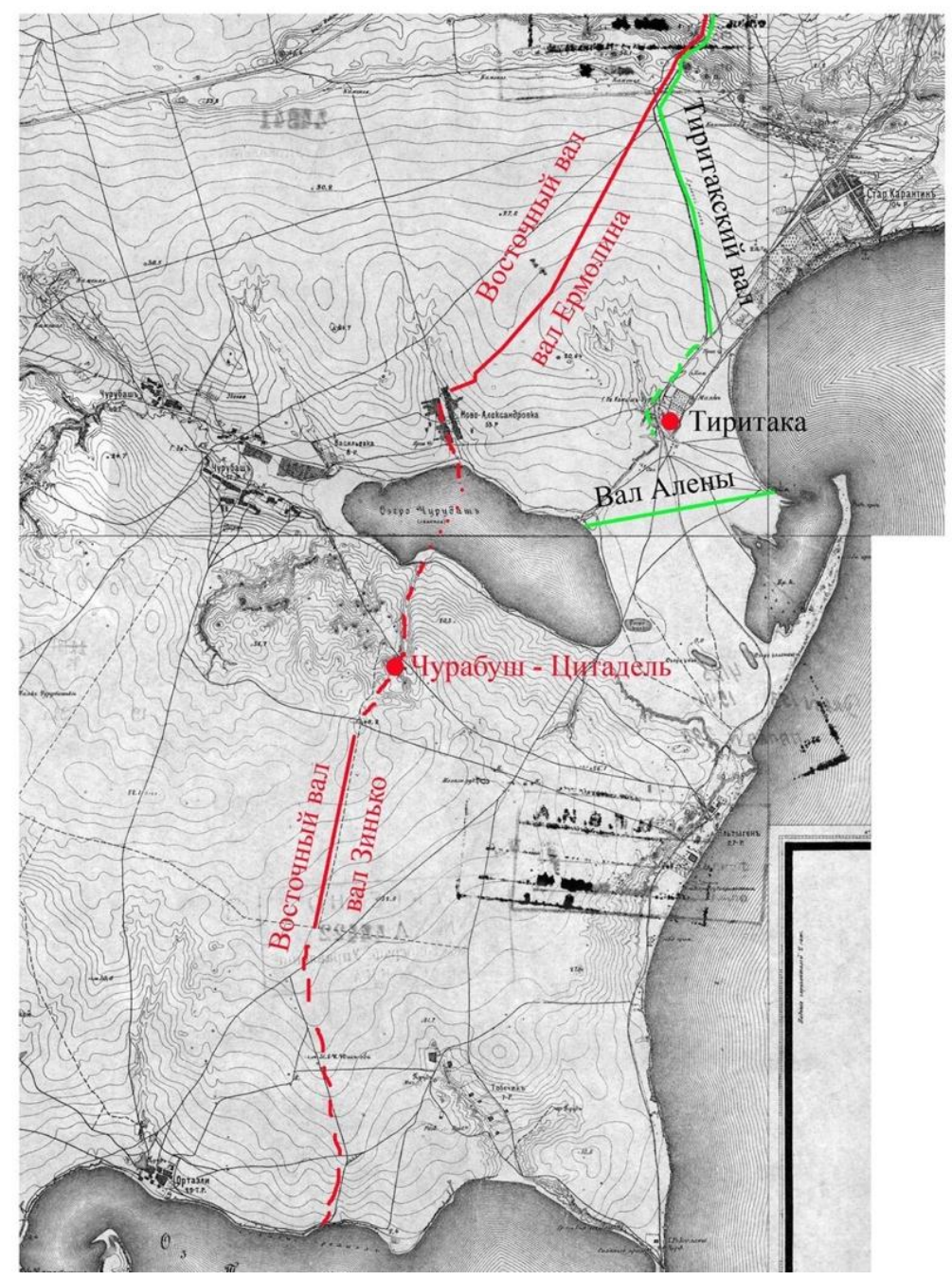

Рис. 13. Тиритакские и Восточные валы. Восточный вал от развилки и до бывш. дер.

Александровка - вал Ермолина. От Александровки и до поселения Чурбаша - Цитадели роль рва выполнял овраг. От Чурбаш - Цитадели и до оз. Тобечик в Восточный вал входит вал Зинько. Карта - «верстовка» 1895 г.

Fig. 13. Tyritakskiy and Eastern shafts. The eastern rampart from the fork to the former. village Alexandrovka - Ermolin's shaft. From Alexandrovka to the settlement Churbash - Citadel the role of a moat was played by a ravine. From Churbash - Chitadel to the lake. Tobechik is part of the Vostochny Val Val Zinko. Map - «layout» 1895

${ }^{38}$ Ермолин А. Дамба в дефиле между оз. Чурбаш и Керченским проливом (вал Алены) https://www.facebook.com/permalink.php?story_fbid=1355198224613424\&id=882128061920445\&_xts_[0]=68. ARDcAPEJCClldB5BCGUI9aM9Tkg5lpMOahrhhHQvb9_JN8y6mTyaeHysYx6021wD_0eBMEVWsrgI0_qnnPebAHMUT-

TkxJKKYUdL47U17op6gAHpzYRi74mC6BZzCr8ab2r9VmcwAqYvMxyC3ZVUB1Eww159x5SSVQ4u09hWmN fQzgetKDH0KDwA9a0jmZdUaRLfn4mheRGIESREbyWK-8ZvQfiqY5hAYb2Yd6ctC-

YJgZHrA5DM0oXkaMjzuwEGU1EgPCjq8YrxFRo6rfSD-Jt4rSaRM2bb9mwic0mSsG64a-k4Qkusw. 
Возвращаемся к Восточному валу: от развилки с Тиритакским валом он идет в сторону быв. дер. Александровка и доходит до оврага у дер. Александровка. Там он заканчивается, точнее, роль рва переходит к оврагу, доходящему до оз. Чурубаш. На противоположной стороне оз. Чурубаш линию обороны продолжает тоже овраг, доходящий до башни - усадьбы Чурубаш - Цитадель I в. до н. э. (рис. 13). Далее за Чурубаш - Цитаделью через 1 км к югу на местности «читается» вал Зинько, описанный как у Т. Шолля [Scholl, Zin'ko, 1999], так и в монографии В.Н. Зинько [Зинько, 2003, с. 43, рис. 19].

И еще о вале Зинько: разведками 2016 г., проводимыми В.Н. Зинько на трассе газопровода в районе вала Зинько, вал не был найден и не был указан в отчете о разведках, а при прокладке газопровода его участок протяженностью около 50 м был уничтожен. Далее вал Зинько, как составляющая часть Восточного вала, доходил до оз. Тобечик (рис. 13).

На противоположной стороне оз. Тобечик эстафету трассы Восточного вала (участка вала Зинько) принимает Кыз-Аульский вал, который был исследован В.В. Веселовым и М.М. Кублановым, описан А.А. Масленниковым. По описанию В.В. Веселова, вал начинался в районе дер. Костырино, шел до Красного кургана и заканчивался в районе КызАульского маяка (рис. 2). Я считаю, что именно этот участок под названием КызАульский вал и был окончанием Восточного вала - Восточной линии обороны. О КызАульском вале можно прочитать в интернете «Археологические открытия Alex Ermolin» от 2 марта 2020 г. «Кыз-Аульский вал. А. Ермолин» ${ }^{39}$.

\section{Выводы}

1. Так называемый Тиритакский вал в представлении ученых-археологов и историков до 2008 г. представлял собой компиляцию из трех разновременных земляных оборонительных сооружений.

2. Большая часть Тиритакского вала проходит по более раннему Восточному валу.

3. Восточный вал датируется по находящимся в его линии крепостям - укрепленным поселениям, датирующимся 60-ми гг. I в. до н. э.

4. Тиритакский вал построен в более позднее время; по нашему мнению, это мог быть год, когда часть гуннов возвращалась из Европы в 453 г.

5. Вал (ров) не доходит до городища Тиритака, а переходит в овраг в 2 км к северу, с юга подходы к Тиритаке прикрывает вал Алены.

6. Характерной особенностью ранних валов является то, что трасса вала проходит по грядам и высотам, повторяя складки местности, в линии этих валов стоят укрепления этого времени - начала I в. до н. э. Валы V в. проложены более прямолинейно с использованием глубоких оврагов, как продолжение рва, например, вал Елены. В линии этих поздних валов нет никаких укреплений, они отгораживают определенную территорию. Скорее всего, они строились в преддверии вторжения сильного и многочисленного противника, скорее всего, прохода гуннских племен через Керченский полуостров.

7. Трасса Восточного вала (Восточной линии обороны) состоит из ранее известных и вновь выявленных отдельных участков: участок вала от берега Азовского моря и до поселения Длинная Крепость, обследованных 11.10.2008 экспедицией под руководством А.Л. Ермолина. Далее идет участок вала, выявленный К.Э. Гриневичем, разведками 19241925 гг. Следующий участок от дер. Войкова и до Золотого кургана выявлен А.А. Мас-

\footnotetext{
${ }^{39}$ Ермолин А. Кыз-Аульский вал -
}

https://www.facebook.com/permalink.php?story_fbid=1909056329227608\&id=882128061920445\&_xts_[0]=68. ARBNL9Wagk6M1SvIps2r0L_G9YM5a7vhFWiXRrw69auVqiDyCdYalPU-

OXKzesz6tTbZIaRNWGtiAdDKg6F5J8tSbvk1nlZsM0NFPzP2T0dHP0DGjFA_cOUbf_Y-

JY4s18AgFhtzIJmFsdJa8LfP0OfmsbvX6G_nwc0W3yC-

19LYs42H0fr_cibBt4v_VO0xYlsYDZdvxc4cHHJzC36K04tyWod-

cyrJ4pZ6zs28phht2VsdJ2fMMYmhHKvWFV0LGmEW_UEs3u_ZtzKepoTDSuQ7-

qMuSyS3BCDa9cIRIJTLxZg8fQS-tA. 
ленниковым по аэрофотоснимкам 1954 г. Здесь вал доходил до реки Мелек-Чесме, где и заканчивался. Продолжался вал по уже видимому в наше время позднему рву и доходил до Золотого кургана. Далее вал исследован В.В. Веселовым от Митридатской гряды и до Второго Змеиного кургана. Следующий участок найден А.Л. Ермолиным от точки в 600 м южнее Второго Змеиного кургана и до быв. дер. Александровка. Этот участок назван вал Ермолина. Следующий вал, входящий в Восточную линию, называется вал Зинько и заканчивается Восточной линией обороны у Кыз-Аульского маяка Кыз-Аульским валом. Протяженность Восточного вала составляет около 52 км, являясь наиболее протяженной оборонительной линией, проходя от Азовского моря до Черного.

8. Тиритакский вал начинается в 1 км от побережья Азовского моря от оврага в быв. ауле Биюк. Тархан довольно прямолинейно доходит до дер. Войкова (быв. аул Катерлез), далее идет по трассе Восточного вала до развилки в 600 м южнее Второго Змеиного кургана, далее поворачивает на север и доходит до оврага в 2 км севернее городища Тиритака; далее овраг, выполняя функции рва, доходит до оз. Чурубаш. Вал Алены фактически является южной частью Тиритакского вала.

9. На трассе как Восточного вала, так и Тиритакского вала есть «белые пятна», которые могут быть обследованы только в ходе охранных работ при прокладке подземных коммуникаций, например, участок Восточного и Тиритакского вала, проходящие в дер. Войкова. На некоторых участках необходимы дополнительные исследования, например, южнее Чурубаш Цитадели и в районе берега оз. Тобечик вала Зинько, о котором очень мало информации. К большому сожалению, не использованы возможности его исследования во время прокладки трассы газопровода.

10. Статья А.А. Супренкова [Супренков, 2020, с. 360-370] имеет такое большое количество неточностей и концептуальных ошибок, что не может считаться научной и не должна приниматься во внимание в библиографии по истории и археологии Боспора.

В статье использован картографический материал, любезно представленный А.П. Пигиным.

\section{Список литературы}

1. Бейлин Д.В. 2015. Поселение Тархан I в Восточном Крыму (по результатам разведок 2009-2012 гг.). Таврийские студии. Международная научно-практическая конференция Археология и история Боспора. К 70-летию Боспорской экспедиции (Пантикапей) 13-14 августа 2015 г. Керчь, 19-28.

2. Веселов В.В. 2005. Сводная ведомость результатов археологических разведок на Керченском и Таманском полуостровах в 1949-1964 гг. Древности Боспора (ДБ). Supplimentum II, 266.

3. Гриневич К.Э. 1946. Оборона Боспора Киммерийского. Вестник древней истории (ВДИ). 2, 160-164.

4. Дюбрюкс П. 2010. Собрание сочинений. Том II. Тексты. СПб., 312.

5. Ермолин А.Л. 2005. Охранные раскопки на территории г. Керчи при прокладке трассы газопровода ГРС (второй Змеиный курган) - ТЭЦ (Тиритака). Древности Боспора, № 8, 171-183.

6. Ермолин А.Л. 2006. Локализация места противостояния гуннов и готов на Керченском полуострове. ДБ. 9, 90-100.

7. Ермолин А.Л. 2010. О датировке земляных оборонительных сооружений Боспора. ДБ. 14: $130-161$.

8. Ермолин А.Л. 2012. Вновь выявленные древние земляные оборонительные сооружения Восточного Крыма: по материалам археологических разведок. Научные ведомости БелГУ. Сер. История. Политология. Экономика. Информатика. 1. Вып. 21. Белгород: 25-33.

9. Ермолин А.Л. 2013. Оборона европейского Боспора во второй половине III в. до н. э. начале I в. до н. э. и таманские аналогии. Научные ведомости Белгородского государственного университета. Серия История. Политология. Экономика. Информатика. № 8 (151) Выпуск 26: $12-23$. 
10. Ермолин А.Л. 2019. Узунларский вал - описание и проблемы датировки. Кондаковские чтения - VI. Белгород: 30-98.

11. Журавлев Д.В., Батасов А.В., Фирсов К.Б., Шлотцауер У. 2020. Раскопки поселения Голубицкая 2 на Таманском полуострове. Археологические открытия. 2018 год. М.: 247-249.

12. Зинько В.Н. 2003. Хора боспорского города Нимфея. Боспорские исследования. Вып. № 4. Симферополь - Керчь, 362.

13. Колтухов С.Г., Труфанов А.А., Уженцев В.Б. 2003. Новые материалы к строительной истории Узунларского вала. ДБ. 6. М.: 176-183.

14. Колтухов С.Г., Ермолин А.Л., Труфанов А.А., Уженцев В.Б. 2006. Разрез Узунларского рва и вала близ шоссе Феодосия - Керчь. ДБ. 10. М.: 340-347.

15. Кругликова И.Т. 1975. Сельское хозяйство Боспора. М., Наука, 300.

16. Масленников А.А. 2003. Древние земляные погранично-оборонительные сооружения Восточного Крыма. М., ИА РАН, 280.

17. Масленников А.А. 2020. Хора Боспора в III-ІІ вв. до н. э. Российская археология. № 1: 76-89.

18. Супренков А.А. 2018. Раскопки на Узунларском валу в 2016 г.: хронология и интерпретация основных построек. ДБ. 23: 230-257.

19. Супренков А.А. 2019. Узунларский вал: к хронологии сооружения по результатам работ 2015-2017 гг. Таврические студии. 19. Симферополь: 103-111.

20. Супренков А.А., Топоривская М.А., Требухина Н.Ю. 2019а. Новейшие археологические исследования на Тиритакском валу и валу Безкровного в Восточном Крыму. Крым - Таврида. Археологические исследования в Крыму в 2017-2018 гг. Т. 1. М.: 177-187.

21. Супренков А.А., Столяренко П.Г., Требухина Н.Ю. 2019б. Исследования вала Безкровного в 2017-2018 гг. и сопутствующий археологический материал. Боспор Киммерийский и варварский мир в период античности и средневековья: Основные итоги и перспективы исследований (Боспорские чтения. ХХ). Керчь: 564-573.

22. Супренков А.А. 2020. Предварительный результаты разведок на валах Восточного Крыма в 2019 г. ДБ. 25: 360-375.

23. Scholl T., Zin'ko V., 1999. Archaeological Map of Nimphaion (Krimea). Warsaw, 292.

\section{Referenses}

1. Bejlin D.V. 2015. Poselenie Tarhan I v Vostochnom Krymu (po rezul'tatam razvedok 2009-2012 gg.) [Settlement Tarkhan I in Eastern Crimea (according to the results of exploration 2009-2012)]. Tavrijskie studii. Mezhdunarodnaya nauchno-prakticheskaya konferenciya Arheologiya i istoriya Bospora. K 70-letiyu Bosporskoj ekspedicii (Pantikapej) 13-14 avgusta 2015 g. [Tavrian studios. International Scientific and Practical Conference Archeology and History of the Bosporus. To the 70th anniversary of the Bosporus expedition (Panticapaeum) August 13-14, 2015]. Kerch', 19-28.

2. Veselov V.V. 2005. Svodnaya vedomost' rezul'tatov arheologicheskih razvedok na Kerchenskom i Tamanskom poluostrovah v 1949-1964 gg. [Consolidated statement of the results of archaeological exploration in the Kerch and Taman peninsulas in 1949-1964]. Drevnosti Bospora [Antiquities of the Bosporus] (DB). Supplimentum II, 266.

3. Grinevich K.E. 1946. Oborona Bospora Kimmerijskogo [Defense of the Cimmerian Bosporus]. Vestnik drevney istorii [Ancient History Herald] (VDI). 2, 160-164.

4. Dyubryuks P. 2010. Sobranie sochinenij [Collected Works]. Tom II. Teksty. SPb., 312.

5. Ermolin A.L. 2005. Ohrannye raskopki na territorii g. Kerchi pri prokladke trassy gazoprovoda GRS (vtoroj Zmeinyj kurgan) - TEC (Tiritaka) [Security excavations on the territory of the city of Kerch during the laying of the gas pipeline route GDS (second Serpentine Kurgan) - TPP (Tiritaka)]. Drevnosti Bospora [Antiquities of the Bosporus], № 8, 171-183.

6. Ermolin A.L. 2006. Lokalizaciya mesta protivostoyaniya gunnov i gotov na Kerchenskom poluostrove [Localization of the place of confrontation between the Huns and the Goths on the Kerch Peninsula]. Drevnosti Bospora [Antiquities of the Bosporus]. 9. M., 90-100.

7. Ermolin A.L. 2010. O datirovke zemlyanyh oboronitel'nyh sooruzhenij Bospora [On the dating of the earthly defensive structures of the Bosporus]. Drevnosti Bospora [Antiquities of the Bosporus]. 4, 130-161. 
8. Ermolin A.L. 2012. Vnov' vyyavlennye drevnie zemlyanye oboronitel'nye sooruzheniya Vostochnogo Kryma: po materialam arheologicheskih razvedok [Newly discovered ancient earthen defensive structures of the Eastern Crimea: based on materials from archaeological surveys]. Nauchnye vedomosti BelGU. Ser. istoriya. Politologiya. Ekonomika. Informatika [Scientific bulletin of BelSU. Ser. History. Political science. Economy. Computer science]. 1. Vyp. 21. Belgorod, 25-33.

9. Ermolin A.L. 2013. Oborona evropejskogo Bospora vo vtoroj polovine III v. do n. e. - nachale I v. do n. e. i tamanskie analogii [Defense of the European Bosporus in the second half of the III century B.C. - the beginning of the 1st century B.C. and Taman analogies]. Nauchnye vedomosti Belgorodskogo gosudarstvennogo universiteta. Seriya Istoriya. Politologiya. Ekonomika. Informatika [Scientific bulletin of BelSU. Ser. history. Political science. Economy. Computer science]. № 8 (151) Vypusk 26, 12-23.

10. Ermolin A.L. 2019. Uzunlarskij val - opisanie i problemy datirovki [Uzunlar shaft description and dating problems]. Kondakovskie chteniya - VI [Kondakov Readings - VI]. Belgorod, 30-98.

11. Zhuravlev D.V., Batasov A.V., Firsov K.B., Shlotcauer U. 2020. Raskopki poseleniya Golubichkaya 2 na Tamanskom poluostrove [Excavations of the settlement of Golubitskaya 2 on the Taman Peninsula]. Arheologicheskie otkrytiya 2018 god [Archaeological discoveries 2018]. M., 247-249.

12. Zin'ko V.N. 2003. Hora bosporskogo goroda Nimfeya [Chora of the Bosporan city of Nymphea]. Bosporskie issledovaniya [Bosporan Research]. Vyp. № 4. Simferopol' - Kerch', 362.

13. Koltuhov S.G., Trufanov A.A., Uzhencev V.B. 2003. Novye materialy k stroitel'noj istorii Uzunlarskogo vala [New materials for the construction history of the Uzunlar shaft]. Drevnosti Bospora [Antiquities of the Bosporus]. 6. M., 176-183.

14. Koltuhov S.G., Ermolin A.L., Trufanov A.A., Uzhencev V.B. 2006. Razrez Uzunlarskogo rva i vala bliz shosse Feodosiya - Kerch' [Section of the Uzunlarsky ditch and rampart near the Feodosia - Kerch highway]. Drevnosti Bospora [Antiquities of the Bosporus]. 10: 340-347. Nauka, 300 .

15. Kruglikova I.T. 1975. Sel'skoe hozyajstvo Bospora [Agriculture of the Bosporus]. M.,

16. Maslennikov A.A. 2003. Drevnie zemlyanye pogranichno-oboronitel'nye sooruzheniya Vostochnogo Kryma [Ancient earthen border-defensive structures of the Eastern Crimea]. M., IA RAN, 280.

17. Maselnnikov A.A. 2020. Hora Bospora v III-II vv. do n. e. [Chora of the Bosporus in the III-II centuries. B. C.] Rossiyskaya archeologia [Russian archaeology]. 1: 76-89.

18. Suprenkov A.A. 2018. Raskopki na Uzunlarskom valu v 2016 g.: hronologiya i interpretaciya osnovnyh postroek [Excavations on the Uzunlarsky shaft in 2016: chronology and interpretation of the main buildings]. Drevnosti Bospora [Antiquities of the Bosporus]. 23, 230-257.

19. Suprenkov A.A. 2019. Uzunlarskij val: $k$ hronologii sooruzheniya po rezul'tatam rabot 2015-2017 gg. [Uzunlar shaft: to the chronology of the structure based on the results of work in 2015-2017]. Tavricheskie studii [Taurian studios]. 19. Simferopol', 103-111.

20. Suprenkov A.A., Toporivskaya M.A., Trebuhina N.Yu. 2019a. Novejshie arheologicheskie issledovaniya na Tiritakskom valu i valu Bezkrovnogo v Vostochnom Krymu [The latest archaeological research on the Tyritaka shaft and the Bezkrovny shaft in the Eastern Crimea]. Krym - Tavrida. Arheologicheskie issledovaniya v Krymu v 2017-2018 gg. [Crimea - Tavrida. Archaeological research in Crimea in 2017-2018]. T. 1. M., 177-187.

21. Suprenkov A.A., Stolyarenko P.G., Trebuhina N.Yu. 2019b. Issledovaniya vala Bezkrovnogo v 2017-2018 gg. i soputstvuyushchij arheologicheskij material [Studies of the Bezkrovny shaft in 2017-2018. and accompanying archaeological material]. Bospor Kimmerijskij i varvarskij mir v period antichnosti i srednevekov'ya: Osnovnye itogi i perspektivy issledovanij (Bosporskie chteniya. XX) [Bosporus Cimmerian and Barbaric World in Antiquity and the Middle Ages: Main Results and Research Prospects (Bosporus Readings. XX)]. Kerch', 564-573.

22. Suprenkov A.A. 2020. Predvaritel'nyj rezul'taty razvedok na valah Vostochnogo Kryma v 2019 g. [Preliminary results of exploration on the ramparts of the Eastern Crimea in 2019]. Drevnosti Bospora [Antiquities of the Bosporus]. 25, 360-375.

23. Scholl T., Zin'ko V., 1999. Archaeological Map of Nimphaion (Krimea). Warsaw, 292. 
Конфликт интересов: о потенциальном конфликте интересов не сообщалось.

Conflict of interest: no potential conflict of interest related to this article was reported.

\section{ИНФОРМАЦИЯ ОБ АВТОРЕ}

Ермолин Александр Леонидович, кандидат исторических наук, научный сотрудник Археологического института Цинмана, Университет Хайфы, г. Хайфа, Израиль

\section{INFORMATION ABOUT THE AUTHOR}

Alex L. Ermolin, candidate of Historical Sciences, Researcher at the Tsinman Archaeological Institute, University of Haifa, Haifa, Israel 